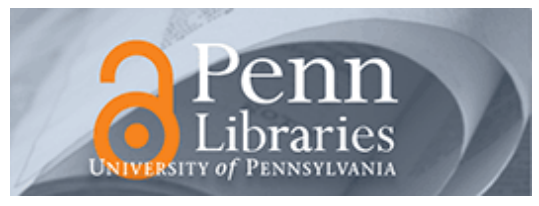

University of Pennsylvania

ScholarlyCommons

Finance Papers

Wharton Faculty Research

2007

\title{
Is the Corporate Loan Market Globally Integrated? A Pricing \\ Puzzle
}

Mark Carey

Gregory Paul Nini

University of Pennsylvania

Follow this and additional works at: https://repository.upenn.edu/fnce_papers

Part of the Finance Commons, and the Finance and Financial Management Commons

\section{Recommended Citation}

Carey, M., \& Nini, G. (2007). Is the Corporate Loan Market Globally Integrated? A Pricing Puzzle. The Journal of Finance, 62 (2), 2969-3007. http://dx.doi.org/10.1111/j.1540-6261.2007.01298.x

At the time of publication, author Gregory Paul Nini was affiliated with the Federal Reserve Board. Currently, he is a faculty member at the Wharton School at the University of Pennsylvania.

This paper is posted at ScholarlyCommons. https://repository.upenn.edu/fnce_papers/289

For more information, please contact repository@pobox.upenn.edu. 


\title{
Is the Corporate Loan Market Globally Integrated? A Pricing Puzzle
}

\author{
Abstract \\ We offer evidence that interest rate spreads on syndicated loans to corporate borrowers are economically \\ significantly smaller in Europe than in the United States, other things equal. Differences in borrower, loan, \\ and lender characteristics do not appear to explain this phenomenon. Borrowers overwhelmingly issue in \\ their natural home market and bank portfolios display home bias. This may explain why pricing \\ discrepancies are not competed away, though their causes remain a puzzle. Thus, important \\ determinants of loan origination market outcomes remain to be identified, home bias appears to be \\ material for pricing, and corporate financing costs differ across Europe and the United States. \\ Disciplines \\ Finance | Finance and Financial Management

\section{Comments} \\ At the time of publication, author Gregory Paul Nini was affiliated with the Federal Reserve Board. \\ Currently, he is a faculty member at the Wharton School at the University of Pennsylvania.
}


Board of Governors of the Federal Reserve System

\author{
International Finance Discussion Papers
}

Number 813

August 2004

Is the Corporate Loan Market Globally Integrated? A Pricing Puzzle

Mark Carey and Greg Nini

NOTE: International Finance Discussion Papers are preliminary materials circulated to stimulate discussion and critical comment. References in publications to International Finance Discussion Papers (other than an acknowledgment that the writer has had access to unpublished material) should be cleared with the author or authors. Recent IFDPs are available on the Web at www.federalreserve.gov/pubs/ifdp/. 


\title{
Is the Corporate Loan Market Globally Integrated? A Pricing Puzzle
}

\author{
Mark Carey and Greg Nini*
}

July 28,2004

\begin{abstract}
We offer evidence that interest rate spreads on syndicated loans to corporate borrowers are economically significantly smaller in Europe than in the U.S., other things equal. Differences in borrower, loan and lender characteristics associated with equilibrium mechanisms suggested in the literature do not appear to explain the phenomenon. Borrowers overwhelmingly issue in their natural home market, and bank portfolios display significant home "bias." This may explain why pricing discrepancies are not competed away, but the fundamental causes of the discrepancies remain a puzzle. Thus, important determinants of loan origination market outcomes remain to be identified, home "bias" appears to be material for pricing, and corporate financing costs differ in Europe and the U.S.
\end{abstract}

Keywords: loans, corporate debt, home bias, market integration, globalization

JEL Codes: G30, G20, G15

* Staff economists of the Division of International Finance of the Federal Reserve Board. Contact information: mark.carey@frb.gov, (202) 452-2784 and gregory.nini@frb.gov, (202) 452-2626. The views in this paper are solely the responsibility of the authors and should not be interpreted as reflecting the views of the Board of Governors of the Federal Reserve System or of any other person associated with the Federal Reserve System. We thank John Ammer, Christa Bouwman, Sally Davies, Bob DeYoung, Craig Furfine, Reint Gropp, Philipp Hartmann, Harry Huizinga, Jan Krahnen, Arvind Mahajan, George Pennacchi, Tony Saunders, David Smith, Jukka Vesala, Steve Weinberg and participants in numerous conference sessions and seminars for useful comments, Dimitri Kiriazov and Duncan Moon of Dealogic for assistance with the data, and Alexandra Resch and Nathanael Clinton for excellent research assistance. 
We offer evidence that prices of syndicated corporate loans differ between the European and U.S. markets, with interest rate spreads smaller in Europe by about 30 basis points on average over the past decade, after controlling for risk and other factors. The differences are economically and statistically significant, with spreads in the European market more than 20 percent less than for comparable loans in the U.S. Levels of differences are larger for riskier borrowers, but differences are roughly proportional to levels of spreads across the risk spectrum. We cannot reject a hypothesis that price differences are as large today as they were a decade ago. We control for a host of factors known (or thought) to affect corporate debt decisions and pricing. Although many controls are correlated with levels of spreads, they have little effect on the price difference across markets.

Such a material difference in pricing can persist only if lenders and borrowers fail to cross borders to such an extent that the difference is not competed away. Though our paper focuses on pricing, we provide some evidence about the location of borrowers' and lenders' activity. The data show that borrowers stay home when they can and that they tend to issue in Europe when they must issue abroad. That is, borrowers domiciled in one of the major markets (Europe, U.S., and Asia) almost always issue in that market. Lenders cross borders more frequently, but still display significant home "bias." 1 About one-quarter of the volume of lending in the U.S. and European markets is provided by lenders headquartered elsewhere, but lenders domiciled in a market region still participate in loans made in that market significantly more frequently than the share of such loans in the world syndicated loan market. This market segmentation likely prevents competition from causing prices to converge in the two markets. ${ }^{2}$

Our results are important to financial intermediation because they imply that economically important determinants of loan prices and quantities remain to be identified in the literature. Our results are important for corporate finance because loans are an important source of firms' external finance and we show that costs of loan finance differ in Europe and the U.S. (Houston and James (1996) find that two-thirds of U.S. firms' total debt is bank debt, and half is bank debt at firms with public debt outstanding). Our results are important to the international finance literature because they are consistent with first-order pricing effects of home bias, not just

\footnotetext{
${ }^{1}$ We borrow the term "home bias" from the international finance literature, which documents that individuals underweight foreign stocks in their portfolios relative to weights suggested by models of optimal diversification. Since these models rely on risk aversion as the fundamental source of demand for diversification, the applicability to presumably risk-neutral banks is not obvious, so "bias" may not be the best term. Nevertheless, since the term is familiar, we use it.

${ }^{2}$ We speculate that the administrative vehicle for home bias is banks' internal country or regional lending limits, which in turn would explain why U.S. borrowers do not flock to the cheaper European market (they would not be welcome if European banks already are at their limits for U.S. exposure). Of course, attributing home bias to lending limits simply translates the home bias puzzle into a limits puzzle.
} 
quantity effects. In passing, we also shed light on hypotheses already in the financial intermediation literature, for example whether the distance between lenders and borrowers matters (Petersen and Rajan 2002; Degryse and Ongena 2005).

Most financial research casts "location" in terms of the domicile of the issuer or the investors. However, the markets in which issuers and investors transact can differ in location from their domiciles. Just as wholesale buyers and sellers of fashionable clothing may meet and transact in New York or Paris even though their firms are located elsewhere, transactions in syndicated loans tend to be centered in London or New York or Hong Kong. We analyze the impact of borrower and lender domicile, but we cast most of our analysis in terms of market location because it is consistent with market practice and because it provides the most illuminating view. The reasons why "market" matters are a subject for future research---this paper only provides evidence that it does. ${ }^{3}$

The natural first hypothesis about pricing differences is that the characteristics of loans and borrowers differ across markets, that is, all else is not equal. Our empirical tests control for a wide variety of factors and mechanisms suggested in the corporate debt and financial intermediation literatures, including potential cross-market differences in: credit risk, non-price terms of loans (e.g. maturity); asymmetric information or moral hazard (Diamond 1984; Berlin and Mester 1992); legal regime (La Porta et al 1997); multi-product package pricing practices; regulation (McCauley and Seth 1992); and others. We find that many of these considerations are material to loan pricing, but the difference in average loan spreads across markets persists, suggesting that the market effect is not due to well-understood differences in the composition of borrower and loan characteristics. Moreover, the pricing difference is not driven by borrowers from a subset of European countries nor by lenders from a subset of countries, nor does it appear to be due to state-owned banks nor differences in regulation across countries.

The natural second hypothesis is that unexplained price differences are due to errors in our data or to weakness of the proxy variables we use in testing hypotheses. It does not appear to be a data problem: The result is remarkably robust, and we have cross-checked key variables with alternative sources. We use multiple proxies for credit risk, which is the most important control variable. A conclusion that weak proxies are at fault cannot be ruled out, but such a conclusion would be an implicit indictment of much of the empirical literature on corporate debt because we use conventional variables and are left with an economically important puzzle.

\footnotetext{
${ }^{3}$ Because borrowers usually stay home, a reader wishing to set aside the "market" concept usually will not go far wrong by translating "market" as "region in which the borrower is domiciled," but such a translation does not capture all the facts.
} 
We cannot reject a hypothesis that our finding is evidence of market inefficiency in the sense of myopic behavior by market participants, but the size of the pricing difference and the sophistication of syndicated loan market participants lead us to discount this possibility. The most active lenders are large banks headquartered in a variety of nations, each with significant international operations. Many lend in both the U.S. and Europe. Moreover, borrowers are large corporations, many with international operations. It is difficult to believe that such market participants would fail to cross oceans in pursuit of lower financing costs due to myopia.

We are left with an economically material pricing puzzle, which appears to be in two parts. One part, home bias, is itself a familiar puzzle in the literature. Whatever causes lender home bias and borrowers' propensity to stay home almost surely contributes to the loan pricing difference by limiting competition. Our paper adds to the importance of the home bias puzzle by providing evidence that it may be relevant for prices. However, regional biases of lenders and borrowers are not a sufficient condition for pricing differences. Some additional factor or friction, some difference in supply or demand conditions, must push loan prices to different equilibrium values in different regions. The existence of this factor or friction is a new puzzle revealed by our paper.

Our evidence is important in other respects. For regulators, one implication is that loan prices should be used with care in banking supervision. Ashcraft and Morgan (2003) suggest that a high incidence of relatively high-spread loans in a bank's portfolio might be evidence of excessive risk-taking. Our evidence implies that controlling for differences in loan and borrower characteristics, including location, may be important to proper regulatory use of loan price information. For macroeconomists, our evidence implies that even large corporate loan markets of major industrial nations may be rather segmented. Thus, domestic regulatory and monetary policies may have more significant impact on the availability and cost of loan finance and economic activity than in a fully integrated world.

This paper contributes to the broader literature on financial integration. One strand of this literature, including Flood and Rose (2003), tests whether the law of one price holds across markets, interpreting rejections as evidence of less than fully integrated markets. Another focuses on portfolio shares and capital flows (Karolyi and Stulz (2002) offer a survey, and Buch, Driscoll and Ostergaard (2004) examine home bias in bank portfolios). A third strand, including Berger, Dai, Ongena and Smith (2003) and Santos and Tsatsaronis (2002), examines whether the nationality of providers of financial services affects prices or quantities of such services. Most of the literature focuses on equity, bond and money markets. Adam et al (2002) offer a review that implies that some markets are integrated while others are not. 
Other papers that empirically examine syndicated loans include Dennis and Mullineaux (2000), which studies syndicated loans in the U.S.; Bae and Goyal (2003) and Casolaro, Focarelli, and Pozzolo (2003), which examine the pricing of internationally syndicated loans; and Angbazo, Mei and Saunders (1998), which reports estimates of factor models for highly leveraged transaction loans.

A question relevant to interpretation of our results is whether spreads on European and U.S. corporate bonds differ on average. Mahajan and Fraser (1986) find that they do not. A thorough investigation using more recent individual-bond data is beyond the scope of this paper (the data and institutional considerations would be quite different than for loans), but we did briefly examine spreads estimated using daily Merrill Lynch bond index yields and swap data for the period 1999-May 2003 for A- and BBB-rated firms. After accounting for duration and currency effects, we find only small mean and median differences in bond spreads. ${ }^{4}$

The remainder of the paper is in five parts. Section 2 describes the data and provides some institutional background. Section 3 presents simple summary statistics about loan flows. Sections 4 and 5 discuss a number of hypotheses about why loan pricing might differ by region and present evidence about their relevance. Section 6 offers concluding remarks.

\subsection{Data and institutional background}

Though loans have been syndicated at least since the Medici era, the market became organized and prominent beginning in the 1960s, serving large multinational corporations, sovereigns, and quasi-governmental entities. Syndicated loans are typically floating-rate debt in which the interest rate paid on outstanding balances is specified as a market-determined base rate plus a spread specified in the loan contract. The rate the borrower pays is reset periodically to reflect the market value of the base rate at the time. The base rate is frequently LIBOR, but EURIBOR, TIBOR and other base rates are also used. All lenders are party to the same debt contract. During syndication, one or more lead lenders seek additional lenders to be party to the contract, relieving the borrower of the need to find lenders and to negotiate a separate contract with each lender.

\footnotetext{
${ }^{4}$ We swapped U.S. and European bond index yields into spreads over dollar LIBOR, and adjusted for the cost of converting the resulting spread, which is denominated in euros, to dollars using forward exchange rates. We then regressed U.S. - European spread differences on the difference and the square of the difference in the average duration of the two Merrill Lynch bond indexes, interpreting intercepts as the adjusted mean difference $\left(\mathrm{R}^{2}\right.$ near 0.5). Intercepts are 1.9 basis points for $\mathrm{BBB}$ and $4.8 \mathrm{bps}$ for A rated bonds. Without the duration adjustment, means (medians) are 21 (12) bps and 10 (5) bps for BBB and A, respectively. All data are from Bloomberg. We do not claim that this is strong evidence of no bond spread difference - that would require careful analysis of individual bond data - but it does corroborate Mahajan and Fraser (1986).
} 
Loans are characterized according to the location of the market in which they are issued as well as by the location of the borrower and the lenders. For example, the early modern syndicated loan market was centered in London and served borrowers from around the world, perhaps in part because London hosted the most important market for the Eurodollar bank deposits that paid LIBOR. That is, most borrowers and lenders were domiciled outside the United Kingdom, but they met to do deals in London, much as transactions in real goods and services may occur in a marketplace distant from the home of the buyer and seller. Today, London, New York, and Hong Kong are the most prominent markets, but smaller markets exist in continental Europe, the South Pacific, and elsewhere (we combine loans from all European sub-markets in defining the European market empirically). Many global banks have separate loan desks in each of these markets that serve local borrowers. Typically, borrowers choose to issue in their local or regional market, and lead banks focus their syndicate-building efforts on banks that commonly participate in that market. ${ }^{5}$

Volumes have become large over the past two decades as the market has come to serve the loan financing needs of many medium-sized corporations. Volumes grew especially rapidly in the United States during the late 1980s and early 1990s, but since 1992 volume has grown somewhat more rapidly in the European and Asian markets than in the U.S. market (Figure 1).

Data on syndicated loans are from Dealogic's Loanware database, which has information about loan borrowers, lenders, pricing, and non-price terms at origination but no information about repayment history. Loanware is broadly similar to Loan Pricing Corporation's (LPC) Dealscan database, but the two differ in coverage, especially in earlier years. LPC's data collection efforts were focused primarily on the U.S. loan market until the late 1990s, whereas entries in Loanware are largely from non-U.S. markets until the early 1990s. We use Loanware because we examine global activity, but we use data only for loans originated during 1992-2002 because Loanware coverage of U.S. loans appears markedly less complete before $1992{ }^{6}$

\footnotetext{
${ }^{5}$ Some banks operate in only one market, typically their home market (the largest banks tend to operate in all markets). Thus, one institutional feature that distinguishes one market from another is that the "rolodex" that lead banks use in building syndicates is somewhat different in each market.

${ }^{6}$ We compared Loanware and Dealscan's coverage of loans by drawing small random samples of loans from each and searching for matching loans in the other database. Dealscan has no or incomplete information for about 80 percent of European-market loans found in Loanware from 1992-97, but overlap is good (about 90 percent) from 1998 on. Dealscan has information for about 80 percent of U.S.-market loans found in Loanware throughout 19922002 and over 90 percent if very small loans are ignored. However, Loanware appears more likely to make minor errors in recording lender identities and roles in the earlier years.

We compared total volumes of U.S.-market loans by year in Loanware and Dealscan and found them to be similar. However, 8 of 22 U.S.-market loans randomly drawn from Dealscan do not appear in Loanware, with no apparent trend in the miss rate. About half the misses are smaller-than-average loans but none are tiny. It may be that the implied undercount in Loanware is specific to the sample, since total volumes of U.S.-market loans in the two databases appear similar. Overall, the facts imply Loanware is the better choice for this paper's purposes.
} 
Ratings are our primary measure of borrower credit quality. Loanware includes ratings, but we also match borrowers by name with Moody's Default Risk Service database, which includes a history of Moody's corporate rating actions, in order to measure the evolution of borrower credit quality after loans are made (Covtiz and Harrison (2003) examine rating migrations). Where both a Moody's and an S\&P rating are available, we use the riskier of the two ratings (results are robust to using just Moody's or just S\&P ratings). ${ }^{7}$

Although a number of previous studies have used accounting ratios as proxies for credit quality, most such studies have focused on U.S. firms, which are subject to uniform accounting standards. We do not focus on such measures because of the difficulty of adjusting the ratios of borrowers in different nations to be compatible; however, our results are robust to the inclusion of standard measures of firm size, leverage, and profitability, as described further below. As an additional measure of credit risk, we use the estimate of borrower default probability ("EDF") produced by Moody's KMV's CreditMonitor implementation of Merton's (1974) model. EDFs are available only for a subset of our pricing sample, as described further below.

We use loans to borrowers domiciled in any nation when examining international loan flows. However, to reduce the problem of unmeasured credit quality correlated with nationality, our pricing sample includes only loans to borrowers in a set of industrialized nations that approximates the membership of the OECD. ${ }^{8}$ Country risk assessments often influence loan pricing and origination decisions for emerging-market borrowers. Although country risk may also affect pricing in our sample, we expect the effects to be much smaller than for emergingmarket borrowers and to be reflected to a greater extent in the ex post rating measures we use as control variables. Results reported later in the paper are consistent with this view.

We control for the nationality of both borrowers and lenders. ${ }^{9}$ It is common for syndicates to involve lenders with different nationalities, and the importance of these lenders may vary as a function of their role in the syndicate. For example, the lead or agent banks in a syndicate are often thought to play a larger role and to be better informed than other participant banks (Dennis

\footnotetext{
${ }^{7}$ About one-quarter of the Moody's ratings reported in Loanware are incorrect, but the majority of the errors are a single tick on the rating scale. Loanware's reported ratings are a little bit riskier than corrected ratings on average, but the bias is similar for loans made in both the U.S. and European markets, as is the error rate.

${ }^{8}$ We use OECD countries, but we omit Poland, Slovakia, Czechoslovakia, and Turkey, and we include in the sample non-OECD countries Hong Kong, Singapore and Taiwan. Other OECD countries in the sample include the U.S., Canada, U.K. including Ireland, Germany, France, Switzerland, Italy, Spain, Netherlands, Norway, Sweden, Denmark, Austria, Portugal, New Zealand, Japan, Australia, Belgium, Finland, Iceland, South Korea, Liechtenstein, Monaco, and Luxembourg. As a practical matter, borrowers from the first dozen or so countries dominate our pricing sample.

${ }^{9}$ Our data allow us to distinguish between the nationality of the parent organization and the particular subsidiary that is borrowing or lending. Our results are not materially affected by the distinction.
} 
and Mullineaux 2000). Consequently, when we examine effects of differences in the nationality of syndicates, we check robustness by using several different sets of variables:

- A dummy variable for whether the syndicate includes any lender or any lead bank with nationality different from that of the borrower.

- A dummy variable indicating whether all lenders or all lead banks have nationality different from that of the borrower.

- Dummy variables that indicate the presence of any lenders from particular nations or regions.

- The fraction of syndicate lenders from each nation or region.

Many loan deals include multiple parts, or 'tranches', such as a line of credit and a term loan. Pricing and the identity of lenders can differ across tranches within a deal, so we use tranches as the unit of analysis, but results are similar if deals are the unit of analysis.

Our primary measure of loan price is an all-in interest rate spread that includes the contract spread over LIBOR on the loan's outstanding balance plus any annual fee and any upfront fee prorated over the life of the loan. Fee information is often missing in Loanware, so we include in factor models a dummy variable for the presence of fee information that helps control for such noise in our pricing measure. ${ }^{10}$ To limit the influence of outliers, we winsorize spreads at the $1^{\text {st }}$ and $95^{\text {th }}$ percentiles for each grade. For example, we set values larger than the $95^{\text {th }}$ percentile to the value at the $95^{\text {th }}$ percentile. Results are robust to use of other percentiles as cutoffs and to use of raw spreads. ${ }^{11}$

\subsection{Loan flows: Who goes where}

Some facts about loan flows are useful background for an examination of pricing differences. If most borrowers and lenders operate only in their home markets then the forces tending to promote price convergence may be weak, although one would still expect similar risks to be priced similarly in long-run equilibrium.

Panel A of Table 1 displays the percentage of syndicated loan volume in the European, U.S. and Asian syndicated loan markets that is due to activity by borrowers in different domiciles (we include Asia to give a sense of global flows, but various issues cause us to exclude Asia from the

\footnotetext{
10 Results are robust to use of contract spreads alone (without fees) as the pricing measure. When fees alone are used, there is no apparent difference in pricing across markets, but the sample is much smaller, and fees are also relatively small, averaging about 8 percent of the spread.

${ }^{11}$ The winsorizing procedure varies only slightly by market, with U.S. loans more likely to have spreads above the $95^{\text {th }}$ percentile and European loans more likely to be below the $1^{\text {st }}$ percentile. This is consistent with the differences in means across markets that we discuss later.
} 
analysis of pricing, as described further below). Panel B shows how borrowers in each domicile allocate their issuance across the three markets. The table reveals that borrowers usually stay home, and that Europe is usually the market of choice for borrowers located outside the three markets. That is, U.S. firms almost always issue in the U.S. market, European firms in the European market, and Asian firms in the Asian market, as shown by fractions in excess of 90 percent in Panel B. However, firms with no natural local syndicated loan market, most prominently Latin American firms and those in the "Other" category, tend to use the European market, not the U.S. market, even though the U.S. market is larger by volume. ${ }^{12}$ Even Canadian firms issue 19 percent of their loans in the European market, which is surprising given the tight integration of U.S. and Canadian financial markets. ${ }^{13}$ Latin American borrowers' preference for the European market does not appear to be due to a preference for Spanish or Portuguese banks; such banks' share of loans to Latin American borrowers is about 10 percent, similar to their share of other European-market loans. It is possible that non-U.S. and non-Asian borrowers use the European market for historical reasons (as noted, London was the center of the market years ago), but it is also possible that firms that must issue far from home choose the cheaper market.

In contrast to borrowers, lenders are more likely to cross borders, at least as a group. The left panel of Table 2 shows that 20 to 30 percent of lending in each market is by out-of-region lenders. By-volume and by-number results are similar except for the U.S., where a difference arises because non-U.S. lenders are more likely to participate in large loans than in small loans. ${ }^{14}$ As shown in the middle panel, lead lenders are somewhat less likely to be domiciled outside the market, especially in the U.S., where only 12 percent of lead lenders are foreign.

Although lenders cross borders more than borrowers, the fractions in Table 2 are small enough to hint that lenders may be subject to home bias (as noted previously, "bias" may not be the best term for the loan market, but we follow the literature's terminology). The degree to which total loan portfolios mimic the world loan portfolio cannot be measured accurately with Loanware data because many bank assets are not syndicated loans (and some syndicated loans

\footnotetext{
${ }^{12}$ This contrasts with equity markets, where firms often choose to issue in the U.S. market (Henderson, Jegadeesh, and Weisbach, 2003). Non-European issuers of public debt are somewhat more likely than issuers of equity to choose European over U.S. markets.

13 Of the 15.1 percentage points of loans by borrowers in "Other" domiciles issued in the U.S. market, 12.9 percentage points were by firms incorporated in the Bahamas, Bermuda and the Cayman Islands. In recent years, some de facto U.S. firms have chosen to incorporate in these tax havens. If these domiciles were viewed as part of the U.S., firms in "Other" nations would be measured as choosing Europe over the U.S. as the market for issuance to an even greater extent than shown in Table 1.

14 Table 2 is based on a subset of Loanware observations for which the shares of each loan's volume provided by each participating lender is known. If the full sample is used to compute results in the left panel by assuming each lender takes an equal share of loans with unreported shares, results are 32, 24 and 19 percent respectively by volume. Results are also similar to those shown in the table when measures are based on numbers of participations.
} 
do not appear in Loanware). However, virtually all banks have substantial volumes of loans that are almost by necessity domestic because such loans are originated to small firms through domestic branches. ${ }^{15}$ Thus, lenders that seek to invest in the world loan portfolio would overweight foreign borrowers in the syndicated-loan portion of their portfolios.

Table 3 presents lenders' portfolio allocations of syndicated loans to borrowers in different regions. For example, the first column shows that U.S.-domiciled lenders channel 91 percent of their syndicated lending volume to U.S. borrowers, 6 percent to European and 3 percent to Other-region borrowers. The right panel gives the share of loan volume to borrowers in each region in the global syndicated loan portfolio as represented by Loanware. This is an estimate of the portfolio shares that would appear in other columns of Table 3 if lenders seek to hold the world syndicated loan portfolio. Like other assets, it appears that syndicated loan portfolios display substantial home bias. ${ }^{16}$ Lenders in each region are overweight borrowers in their home region by about 30 to 40 percentage points. That is, the degree of home bias is similar for lenders in different regions. ${ }^{17}$

The final row of Table 3 gives the shares of lenders from each region in the global market. U.S. lenders' share, at about 50 percent, is smaller than U.S. borrowers' share, which is about 67 percent (the latter not shown in table), whereas European and Other-region lenders' shares are somewhat larger than those of borrowers from the same region.

\subsection{Pricing: Univariate statistics, base factor model, and the usual suspects}

As noted, we focus on the U.S. and European markets in analyzing pricing and we restrict attention to borrowers from industrialized nations. In part, we do so because we expect integration to be most complete for these markets and borrowers. Moreover, we usually omit Asian loan markets because usable loan samples are relatively small and because the 1997 Asia crisis complicates interpretation of results. We omit borrowers from emerging-market nations because a greater role for country-risk effects on borrower credit quality complicates analysis and interpretation.

We examine all-in interest rate spreads at origination because all our sample loans are floating-rate instruments, so borrowing costs differ across firms only to the extent that spreads

\footnotetext{
15 Commercial banks dominate lending in the syndicated loan market.

${ }^{16}$ Buch, Driscoll, and Ostergaard (2003) also find that banks from France, Germany, the U.K. and the U.S. display a home bias in their aggregate asset portfolios.

${ }^{17}$ If shares are computed separately for rated and unrated borrowers, lenders are more overweight the unrated firms in their region, but are economically significantly overweight both rated and unrated borrowers. Thus, home bias characterizes our pricing sample as well as in the full sample.
} 
and fees differ. ${ }^{18}$ The main challenge is controlling for differences in borrower characteristics and in the non-price terms of loans, particularly credit risk, since that is the primary risk borne by lenders. ${ }^{19}$

Ratings are our primary measure of credit quality. Table 4 displays the distribution of loan volume in each market by agency grade for loans to borrowers for which we have a rating at the time the loan contract was signed. As noted, we use the riskier of Moody's and S\&P's rating if both are available (results are qualitatively similar if we use one or the other). Loans to belowinvestment-grade borrowers are substantially less common in the European market, whereas AAA and AA-rated borrowers are more common. That we require a rating for the borrower at issuance greatly reduces the size of the sample usable for pricing analysis. Many borrowers are not rated, especially in the European market, and Loanware does not always report ratings for rated borrowers, although our match to Moody's DRS database mitigates the latter problem.

Table 5 shows that simple mean spreads differ in European and U.S. markets. The first two columns of the left panel display mean spreads by grade for the U.S. and European markets for the whole period 1992-2002 for loans to borrowers in industrialized nations. Pricing is similar on average for the AA and A grades, but spreads are 27, 54 and 66 basis points smaller on average in the European market for the BBB, BB, and B grades, respectively. Differences are somewhat less dramatic when borrowers from emerging-market nations are included in the sample, as shown in Panel B of the table, consistent with such borrowers often paying higher spreads than OECD firms and with such firms issuing mainly in Europe.

Non-price characteristics of loans differ somewhat across the two markets, as shown in Table 6. The left panel has averages for the full sample and the right panel for the pricing (regression) sample to give a sense of how the two differ. Focusing first on the pricing sample in Panel B, although a number of characteristics are similar on the whole, original maturities are about a year longer in the European market, average loan sizes are quite a bit larger, secured loans are less common, and special-purpose financings and government-affiliated borrowers are more common. $^{20}$ Several such differences are related to differences in rating patterns across the two

\footnotetext{
18 Costs might differ if floating base rates differ across contracts, for example LIBOR versus EURIBOR, but all loans in our pricing sample have LIBOR base rates.

${ }^{19}$ Prepayment risk driven by credit quality changes might be materially different across the two markets. Most corporate loans are prepayable without penalty, so borrowers with improving credit quality tend to refinance in order to obtain smaller spreads. However, as discussed further below, post-issuance rating migration rates are similar in the European and U.S. markets, so prepayment risk seems likely to be similar on average. Interest-rate driven prepayment risk is immaterial because loans are floating-rate.

${ }^{20}$ We speculate that the small incidence of lines of credit in Europe in the full sample is associated with the popularity in Europe of demand deposit accounts with overdraft privileges. The share of lines of credit is similar in Europe and the U.S. in the rated sample. We speculate that rated firms, which are larger, need large amounts of flexible financing, implying a need for overdraft facilities at many banks, which is cumbersome to manage.
} 
markets. ${ }^{21}$ Similarly, most of the differences between the full sample (Panel A) and the regression sample arise because the unrated firms that appear in the full sample differ in size from rated firms. ${ }^{22}$

\subsection{Base specification}

The differences in characteristics shown in Table 6 (or other differences in market composition) may account for the differences in spreads in Table 5. We test hypotheses about determinants of differences in spreads by estimating ordinary least squares factor models for spreads that include various combinations of control and proxy variables. Panel 1 of Table 7 reports results for a base-case specification that includes:

- Dummy variables for each tick on the agency rating scale. The omitted category is loans to borrowers rated $\mathrm{A}+$, the safest in the sample, so estimated coefficients measure the premium that successively riskier borrowers paid on average across the two markets. Estimated values increase monotonically and magnitudes appear reasonable. We drop loans to borrowers rated AA- or better because their number is so small that estimation problems accompany their inclusion.

- Dummy variables for changes (migration) of the borrower's Moody's rating during the year following the loan origination date for that part of the sample we were able to match to the Moody's database. The omitted category is no migration. We include migration variables to at least partly control for some likely defects of agency ratings as indicators of credit risk: 1) Agency ratings alone may be incomplete descriptors of credit risk. Such ratings represent long-run average or stress-scenario views of credit risk that often do not reflect shorter-term variations in risk that may be priced by lenders; 2) Ratings are often described as somewhat stale indicators; and 3) Banks are often thought to possess private information about borrower credit quality beyond that possessed by the agencies. Estimated coefficients imply that loan spreads reflect some of the information that later appears as downgrades and upgrades. Results are qualitatively similar if the base rating used in computing migrations is dated three months after the loan origination date, implying that the measured effects are due more to private information in banks' possession than to stale ratings. Coefficients are somewhat smaller in absolute value

${ }^{21}$ Fewer firms are rated in Europe and those that are rated are even more likely to be very large than in the U.S. (and large firms tend to issue large loans). The fraction of investment-grade borrowers is larger in Europe than in the U.S. and low-risk firms are less likely to post collateral.

${ }^{22}$ To provide a sense of the range of the two continuous variables in Panel B of Table 6 , the $25^{\text {th }}$ and $75^{\text {th }}$ percentiles of maturity are 1 and 5 years for the U.S. market, and 3 and 5.5 years for the European market. For loan size, the U.S. $25^{\text {th }}$ and $75^{\text {th }}$ percentiles are $\$ 151$ and $\$ 726$ million, and the European-market counterparts are $\$ 200$ and $\$ 961$ million, respectively. Note that $\$ 961$ million is below the mean for the European market, implying considerable skewness of the European market's loan size distribution. 
when the horizon for migration is two years rather than one, implying that banks' ability to anticipate credit quality changes decreases with the time horizon. The dummy for "no migration information" takes a value of one for loans to borrowers that we were unable to match to the Moody's database. Migration rates are similar for loans issued in the U.S. and European loan markets (not shown in tables). If dummies that interact "European market" with migration dummies are included, the only statistically significant coefficients are for downgrades of 2 or 3 ticks and of 4 or more ticks, and these have opposite signs. We view this as evidence that ex ante pricing of migration is similar in the two markets.

- Dummy variables for the year of loan origination, with 1992 the omitted category. Estimated coefficients imply that, relative to 1992, 1993-1998 were years of lower expected credit risk, but spreads moved higher beginning in 1999, coincident with increased corporate bond default rates, the aftermath of the Russian debt default crisis of 1998, and the advent of the euro. These results are consistent with known variation in expected default rates by grade at short to medium horizons.

- The natural logarithm of the face amount of the loan commitment expressed in dollars. Larger loans typically carry lower spreads, all else equal. Prior research has suggested several possible reasons, including larger borrowers' greater transparency and access to capital markets (such borrowers typically issue larger loans), and fixed costs of making the loan. The impact of firm size is discussed below.

- A dummy for term loans, which are typically fully drawn at issuance, and a dummy for bridge loans and loans of unknown type. The omitted category is lines of credit. Coefficients imply that loans likely to be at least partly drawn at issuance carry economically significantly higher spreads.

- Dummies for the stated purpose of the loan, including takeover and recapitalization finance; loans financing ships, aircraft, and special-purpose vehicles; project finance; and commercial paper backups. "General corporate purposes" is the omitted category. The results indicate that loans financing takeovers are more risky while backup lines are less risky.

- A dummy for loans for which fees are included in the all-in spread. Fee information is missing for some Loanware records. This variable helps to control for biases arising from such omissions. As noted previously, results are robust to use of spreads as the pricing measure, that is, ignoring all fees. 
- A dummy for loans involving multiple obligors (such obligors are typically affiliated with each other), and a dummy for borrowers that are government-owned or affiliated

- 21 dummies representing our judgmental coding of the industry of the borrower, not shown in the table to save space. Most coefficients are small and not statistically significant, but state-owned banks and oil-industry borrowers pay smaller spreads, whereas real estate, telecom, and leisure-industry borrowers pay higher spreads.

Our base specification does not include a control for the currency of the loan, but results are robust to inclusion of dummy variables for the currency in which the loan is denominated. ${ }^{23}$ We omit currency from the base specification because the currency of non-dollar loans is highly correlated with borrower domicile, which is analyzed below.

Coefficients on almost all the aforementioned variables (apart from industry dummies) are statistically and economically significant. However, estimated coefficients on two dummy variables indicating issuance of a loan in the European market, shown in the second and third rows of Table 7, are negative and economically and statistically significant, implying that crossmarket differences in the incidence of characteristics included in the regression do not account for the smaller spreads observed in Europe. The two variables split the sample period into 199298, during which spreads were lower by about 20 bps in Europe relative to the U.S., and 19992002, during which spreads were about 40 bps lower (the average difference over 1992-2002 is 29 bps, not shown). The p-value for a hypothesis that the coefficients are equal is less than .0001 . We chose to split the sample at 1999 because that year marked the beginning of use of the euro, because the recent bulge in corporate default rates began in that year, and because the Asian and Russian crises were in 1997-98.

Panels 2 and 3 of Table 7 split the sample into loans to investment-grade and junk borrowers, respectively. Coefficients on the European market subsample dummies are again all negative and significant, but they are much more negative for the below-investment-grade sector, and the difference in coefficients for the two periods is significant only for junk, not for loans to investment-grade borrowers. Values of coefficients on the control variables differ in panels 2 and 3 , but patterns of sign and significance are generally similar.

The factor model imposes the assumption that the same factor is priced similarly in the U.S. and Europe. Although this assumption can be rejected for some factors, interacting variables with market of issuance leaves the pricing difference across markets unchanged for the mean

\footnotetext{
${ }^{23}$ Almost all U.S.-market loans, and more than half of European-market loans, are denominated in U.S. dollars. Of the remaining European-market loans, about one-third are in U.K. pounds, about one-quarter in euros, and the remainder are dominated by pre-euro French francs and Deutsche marks, with a smattering of other currencies.
} 
loan. We also estimated the base case model for a few subsamples, including only term loans, only lines of credit, only loans falling in a given maturity range, and only loans with a given purpose, and found qualitatively similar results for the difference in pricing across markets.

In remaining tables, we employ a piecewise strategy in adding factors to the model. For each of several hypotheses, we report results of adding only factors relevant to that hypothesis to the model. This is largely to keep the presentation tractable. Table 15 reports results when a representative set of all factors are included, but it does not show every variant that appears in Tables 7-13.

\subsection{Seniority and maturity}

The base specification omits a number of characteristics that Loanware records, including original maturity, guarantees, secured status and amortization features. Although we suspect data on guarantees, secured status and amortization are incomplete, we have no reason to believe the measurement error differs across markets. However, default risk may be related to these loan characteristics. Moreover, the loss given default (LGD) that lenders expect also affects expected losses and spreads, and loan terms like collateral and guarantees affect LGD. Thus, systematic differences in such non-price terms across markets might be responsible for observed differences in pricing.

We omit these variables from the base specification in order to make it relatively free of concerns about simultaneity (these variables are especially likely to be determined simultaneously with spreads). Results when indicator variables for these features are added to the base specification are reported in Table $8 .{ }^{24}$ Coefficients on the added variables are statistically and economically significant, apart from the bullet-loan dummy, but there is no material change in the coefficients on the European-market dummies relative to the values in Table 7. As has been found previously (Berger and Udell 1990), coefficients on the guarantee and collateral variables are generally positive even though such terms are expected to reduce LGD, no doubt because riskier borrowers are more likely to pledge collateral and obtain guarantees. $^{25}$

Systematic differences in LGD between the U.S. and Europe as a whole, perhaps due to differences in bankruptcy regimes, would influence loan spreads even if non-price terms of loans are similar. However, several pieces of evidence imply that LGD differences do not explain our pricing puzzle. To explain the difference in spreads we observe, LGDs would have to be better

\footnotetext{
24 Results on the European market dummy are qualitatively unchanged if we omit loan size and the term loan and bridge loan dummies from the base specification. These variables may also be endogenous.

${ }^{25}$ We can reject hypotheses that coefficients on the maturity dummies are the same, both for all three coefficients and pairwise. Thus, our data imply a non-linear relationship between spreads and maturity.
} 
for European borrowers (which comprise most of our European-market sample) than for U.S. borrowers. Moody's (2003) offers evidence that they are worse: Mean LGD is about 76 percent in Europe and about 65 percent in the U.S. Moody's figures are for bonds, not loans, but conversations with bank regulators, who have done unpublished studies of loan LGDs, and with European bankers, all imply that LGDs for loans in Europe are higher as well. Moreover, regional differences in LGD should also be associated with systematic differences in bond spreads, other things equal, but as noted previously, available evidence implies bond spreads are similar. Because bankruptcy regimes vary across European countries, it is possible that one or two countries might have low average LGDs and that this could cause our result if many of our sample loans are to borrowers in these countries. However, in this case, we should find that borrower-country effects explain the U.S.-Europe spread difference. As described further below, we cannot reject a hypothesis of no country effects within Europe.

\subsection{On the whole, no trend}

Figure 2 sheds more light on how average pricing differences across the two markets vary by grade and over time. It displays estimates of year-by-year differences in spreads across the two markets in the form of coefficient values on interactions of a European-market dummy with year-of-issuance dummies from regressions estimated separately for each grade (un-interacted time dummies are also included, so those shown in Figure 2 are marginal effects). A and BBB grades are in the top panel and BB and B in the bottom. Only 4 of the 44 coefficients are positive. Although the top panel appears to display no trend, a bit of a trend toward relatively lower European market spreads appears to be present for the junk grades. Table 9 displays only coefficients for the 1992-98 and 1999-2002 European market subperiod dummies from separate regressions for each grade. Coefficients become less negative for loans to both A and BBB-rated borrowers, and more negative for both BB and B grades, although the differences are statistically significant only for A and B.

Even though some hypotheses of equality of spread differences over time are rejected, we are not persuaded that trends exist in loan spread differences across the two markets. The apparent trend toward convergence of pricing for loans to A-rated borrowers is driven by the unusual year-2000 observation that is evident in Figure 2. And the pricing sample includes only 39 European-market loans to B-rated borrowers during 1999-2002. We are reluctant to conclude that there has been a trend away from pricing convergence based on such a relatively small subsample. 


\subsection{Borrowers in one or a few countries do not drive the result}

We also explore whether pricing differences or trends are driven by loans to borrowers in just one or a few countries. Table 10 reports the number of sample loans made in the European market to borrowers from each of several groupings of countries. The relatively small numbers of loans issued by firms in European countries, especially for the junk grades, limits our ability to sharply distinguish among some hypotheses related to nationality. Table 11 reports results from regressions that include dummy variables for each group of nations for each of the two subperiods, with the sample used to produce panel 1 limited to investment-grade loans and panel 2 to junk. All control variables from the base specification appear in these regressions, but nonrating, non-time variables are not shown in Table 11 to make space for the country dummy coefficients. Focusing first on the investment-grade case, all but one country coefficient is negative, and though magnitudes differ, on the whole values are rather similar across nations, except that coefficients are more negative for loans to borrowers domiciled in Mediterranean countries and in rest-of world countries. However, dropping these countries from the regressions reported in Table 7 leaves results qualitatively unchanged (the market-dummy coefficients become just a little less negative). ${ }^{26}$ Moreover, a hypothesis that coefficients are equal for all other country-groups is not rejected.

Results are broadly similar for the junk segment (panel 2), but here the Germanic countries are those with a coefficient statistically significantly different from the rest of the pack, and only for 1999-2002. As shown in Table 10, the sample includes only two loans to Germanic belowinvestment-grade firms. Dropping them from the sample does not materially affect overall results.

In addition to the infrequent rejection of hypotheses of equality across countries, the addition of these variables to the base specification increased adjusted- $\mathrm{R}^{2}$ values only by .007 and .001 for the investment-grade and junk cases, respectively. Thus, on the whole, the apparent difference in pricing across markets appears to be a regional or market phenomenon rather than being country-specific.

Loans issued by U.S. borrowers in the European market are especially interesting because borrower nationality is the same for them regardless of the market in which they issue. ${ }^{27}$ Such borrowers paid spreads similar to those paid by European firms during 1992-98 (that is, smaller

\footnotetext{
${ }^{26}$ Numbers of observations are relatively small for these countries. Moreover, most sample loans to Italian and Greek firms are to government-related and bank borrowers. Thus, their effects on averages were partly controlled by industry dummies.

${ }_{27}$ Although only about half a percent of all European market loans are to U.S. borrowers, over ten percent of our pricing sample is loans to U.S. borrowers because U.S. firms are far more likely to be rated than European firms.
} 
than in the U.S. market). During 1999-2002, their spreads were not statistically significantly different from those paid in the U.S., but the sample includes only eleven European market loans to U.S. borrowers during 1999-2002, a number far smaller than during 1992-98. Thus, we are reluctant to interpret the 1999-2002 coefficient as evidence of convergence toward prices that are similar across markets, especially since the point estimates are still less than zero.

\subsection{Pricing: Hypotheses from the financial intermediation literature}

The evidence in the previous section strongly suggests that spreads are lower in the European market for otherwise similar loans and borrowers. However, the factor models reported in Tables 7-11 control only for the most obvious loan and borrower characteristics. The literature on corporate finance and financial intermediation is rich with reasons why loan markets may depart from the simple homogenous-good, competitive-market paradigm. In this section, we review several possible explanations for pricing differences and present evidence related to each. Our ability to test some of the explanations is limited by the limitations of available data.

\subsection{Asymmetric information effects}

Diamond (1984) and James (1987), among many others, argue that banks mitigate problems of asymmetric information. Degryse and Ongena (2005) and Petersen and Rajan (2002) focus on the effect of distance on information costs and lending, and Hadlock and James (2002) note that some firms may choose to issue in higher-cost markets in which their quality is not clearly revealed. Taken together, the body of such work suggests that the identity of lenders may matter; that is, the same borrower might pay different spreads to one set of lenders than to another because of differences in lenders' information about the borrower's credit quality. The existence of such differences may represent a constrained efficient outcome if some borrowers wish to avoid revealing their type. ${ }^{28}$

Loan size and rating migration variables may control for asymmetric-information effects to some extent, but not completely. If lenders' ability to mitigate information problems is correlated with differences in lender and borrower nationality, and if lender nationality patterns differ across markets, then observed differences in pricing might be due to information effects. We offer evidence about this hypothesis by including measures of syndicate nationality in the base-case factor model. We add indicators for the presence of any lender with nationality different from that of the borrower and for any lead lender with nationality different from that of

${ }^{28}$ Boot and Thakor (2000) argue that loans should be divided into transaction-oriented and relationship-oriented categories, with the former economically similar to publicly issued debt. Those loans that are transaction-oriented seem especially likely to be issued in the syndicated loan market, but there is no obvious reason why the pricing of transaction-oriented loans should differ across the U.S. and European markets. 
the borrower, both separately and together. In another set of regressions, we add variables measuring the fraction of lenders with nationality different from that of the borrower and the fraction of lead lenders with different nationality, again both separately and together; and in other regressions whether there are any, and the fraction of, lenders and lead lenders from outside the borrower's home region, again separately and together. We would expect economically statistically significantly positive coefficients on (at least some of) these variables if differences in lender and borrower nationality make it more difficult for lenders to understand borrower credit quality.

Results for these variables are not shown in tables because in no case does their addition have a material effect on the coefficients of the European market dummies. Moreover, coefficients on the additional variables are economically small and never statistically significant for investment-grade loans. In seven of the dozen regressions involving only junk loans, at least one of these variables is statistically significant at the ten percent level, but magnitudes are small (usually around an implied 5 basis point maximum effect) and signs differ. Most of the significant cases involve lead-lender variables, that is, the presence of any lead lender (or a higher fraction of lead lenders) with nationality different from the borrower is associated with higher spreads. However, a higher fraction of lenders in any role with nationality different from the borrower is associated with slightly smaller spreads.

It seems less likely that lenders of different nationality would differ in their ability to mitigate information problems for all borrowers. However, we test an observationally similar hypothesis in the next subsection and find little support.

Overall, the data offer little support that differences in lender ability to mitigate information problems are at the heart of the cross-market pricing differences we observe. It is important to note that our results do NOT imply that asymmetric information is unimportant. The statistical and economic significance of loan size and rating-migration variables could be interpreted as evidence that asymmetric information is generally important in the syndicated loan market. However, our evidence does imply that lenders' ability to manage information problems is not stronger for borrowers located in their own domicile or region, implying that nationality differences per se, or distance per se, are not particularly important to syndicated loan pricing.

\subsection{Ex post monitoring}

Berlin and Mester (1991) and Smith and Warner (1979) suggest that loan covenants and loan renegotiation play an important role in alleviating moral hazard, especially asset substitution. Carey, Prowse, Rea and Udell (1992) and Carey, Sharpe and Post (1998) extend the idea, arguing that differences in lenders' tendency to hold up borrowers during renegotiations, and 
lenders' reputation for doing so, are an important determinant of the structure of financial markets. A lender with a reputation for agreeing to reasonable contract revisions is preferred by borrowers, other things equal, and can charge higher spreads at origination, but such a lender must protect its reputation by avoiding borrowers that will require harsh discipline because such discipline will harm the lender's reputation. It is possible that lenders of different nationality may have renegotiation policies and reputations that differ because of differences in homemarket law, regulation, and financial system structure. A lender that chooses renegotiation policies that are optimal for its domestic market may essentially offer a different loan product in the eyes of global syndicated loan market borrowers than a lender from another nation, and thus spreads may differ with lender nationality.

This hypothesis might explain cross-market differences in pricing if the share of lenders with each nationality differs across markets and if lender nationality is correlated with pricing. However, as shown in Table 12, when we add to the base specification a set of variables giving the fraction of lenders falling in the same nationality-groups employed in Table 11, or the fraction of lead lenders with each nationality (right columns of Table 12), most coefficients are economically small and statistically insignificant and the coefficients on the European market dummies are similar to those of the base case (the fraction of U.S. lenders is the omitted category). Moreover, even for lender nationalities that appear significantly related to spreads, the pattern of results does not conform to intuition about monitoring. For example, a high faction of lenders from Mediterranean nations is associated with much smaller spreads for investment grade borrowers (first column of Table 12). If the monitoring hypothesis is correct, such lenders must have a tendency to hold up borrowers in renegotiations and thus must accept smaller spreads at origination. However, renegotiations are generally thought to be more likely for riskier borrowers, and the lead lenders in a syndicate are often thought to play a particularly important role in renegotiations. Thus, we would expect the Mediterranean-lender effect to be even stronger in the other columns of Table 12, and yet the opposite is the case.

Another implication of the monitoring hypothesis is that the presence of lenders with a given nationality in a syndicate should have the same impact in both the U.S. and the European markets because a lender's reputation is likely to be global. We omit the market-time period dummies from the regressions but interact them with the lender nationality variables. Hypotheses of equality of coefficients across markets for lenders for a given country can be rejected for about half the country groupings (not shown in tables), but the rejections differ for investment-grade and junk cases (French, Japanese and rest-of-world for the investment grade case, and French, German and Nordic lenders for the junk case). 
On the whole, these results do not support the monitoring hypothesis, but again it is important to note that the results do NOT imply that monitoring is an unimportant activity of banks, only that differences in lender nationality per se do not appear strongly related to loan pricing. In passing, these results also hint that the distance between lender and borrower headquarters does not matter much for pricing in the syndicated loan market. This is unsurprising, but different than in the small business loan market (e.g. Degryse and Ongena 2005).

\subsection{Multiproduct package pricing}

Market participants often suggest that loan spreads are related to the amount of other business that lending banks do with the borrower (see also Drucker and Puri 2004). If the incidence of such bundling differs across markets it might account for the differences in pricing we observe. Although we observe only loans and not other purchases from banks, we expect that any bundling effects would grow weaker the larger the number of lenders in the syndicate and the larger the number of small lenders in the syndicate. This is because all syndicate members receive the same contract interest rate spread. It seems unlikely that a large number of banks would all achieve similar sales of ancillary business to the borrower. Moreover, small banks seem less likely to be involved in ancillary business because the range of products they offer is typically narrower than at large banks. Thus, this hypothesis implies that loans involving more small banks should carry higher spreads. ${ }^{29}$

To control for package-pricing effects, we include in separate variants of the base-case factor model: 1) Dummy variables for the number of lenders in the syndicate; and 2) Dummy variables for the number of "small" lenders in the syndicate. Our measure of bank size is based on the number of Loanware database loans in which the lender and its parent or affiliates participate. A "small" lender is one that was party to less than 1000 loans. ${ }^{30}$

Results for these variants are reported in Table 13. Coefficients on a number-of-lendersgreater-than-20 dummy variable are positive and significant for both investment-grade and junk regressions, consistent with the hypothesis (3-to-6 lenders is the omitted category). However, the coefficients are rather small economically, European-market dummy coefficients are essentially unchanged from the base case, and for junk loans the coefficient on a 7-to-20 lenders dummy is negative and significant. Coefficients on dummies indicating loans with four or more

\footnotetext{
${ }^{29}$ Although upfront fees may differ across lenders in a syndicate, such fees are typically larger the larger the lender's share of the loan, which goes the wrong way in terms of compensating small participants receiving little ancillary business.

${ }^{30}$ Only 88 banks are large lenders by this criterion, and they account for more than 75 percent of the appearances of lenders in syndicates.
} 
small lenders are positive and significant for both junk and investment-grade cases, and the coefficient for the junk case is economically material, but again the European-market dummy coefficients are not materially different than in Table 7.

We interpret these results as weak support for the existence of package pricing. It is possible that the negligible impact on European market dummy variable coefficients occurs because syndicate size is a poor proxy for the importance of multiproduct influences on loan pricing, or that package-pricing considerations are generally more important in Europe than in the U.S. even if cross-sectional variations are similar (which would be not captured by our testing strategy). However, it is not clear why package-pricing effects would be stronger on average for belowinvestment-grade borrowers, which would be necessary to explain the pattern of spread differences we observe. Overall, we cannot rule out that package pricing accounts for the pricing differences we observe. However, neither do the data strongly support the hypothesis. ${ }^{31}$

\subsection{Rating agencies apply different standards to different borrowers}

Many non-U.S. borrowers complain of a U.S. bias on the part of Moody's and S\&P. If such rating agencies grade non-U.S. borrowers as riskier than actually-equivalent-risk U.S. borrowers, we would expect to see lower average spreads in the European market, which is dominated by European borrowers, than in the U.S. market. In this case, European borrowers assigned a given agency grade would be safer than U.S. borrowers in the same grade and would borrow at lower spreads, presuming the market perceives and prices risk correctly.

This explanation is difficult to test directly because it amounts to a hypothesis of omittedvariable bias in our factor model results and a perfect proxy for such bias is not available. Moreover, our sample of European loans is too small to provide meaningful measures of ex post default rates by grade, which in a large sample and in the long run should reveal any bias.

However, several pieces of evidence weigh against this hypothesis:

- Ammer and Packer (2000) find no evidence of geographic differences in default rates by grade.

- We include a measure of credit risk that should be unaffected by any rating bias. We matched the pricing sample with a database of month-end KMV EDFs for North American, European, and Asian firms from 1999 on (we were able to find EDFs only for about $60 \%$ of observations). When EDF is included in base-case regressions using this

\footnotetext{
31 We added other measures of lender size and reach to the base specification. First, constructed a variable for the fraction of lenders operating only in the borrower's market region. The variable was not significant and had no impact on pricing differences across markets. Second, we examined whether loans involving small versus large lead banks are priced differently, where "small" is defined in the manner described previously. The variables were generally not significant and had no impact on pricing differences.
} 
reduced sample, both overall and separately for investment-grade and junk-rated firms), its coefficient is positive and significant, but the European-market dummy coefficients are similar to values obtained in the same subsample without EDF. Rating dummy coefficients also remain similar. KMV's model is calibrated using defaults of U.S. firms, so it is possible that the calibration may not be as appropriate for European firms as U.S. firms. However, even if biased, EDFs are unlikely to have the same biases as ratings, so including EDFs in the model should reduce the European market effect if the effect is an artifact of rating biases, but no material reduction occurs.

- Average bond spreads by grade should differ across the two markets if ratings are biased, not just loan spreads, but Mahajan and Fraser (1986) find no difference, and our simple empirical exercise discussed previously corroborates their finding.

- U.S. firms should pay the same spreads in the European market and in the U.S. market, but results presented previously imply otherwise.

- If ratings are biased by borrower nationality, it seems likely the bias would be smaller for the industrialized European nations that form the bulk of our pricing sample, and especially for the U.K., which has a market-oriented financial system similar to the U.S. Thus, we would expect differences in European- and U.S.- market simple mean spreads in Table 5 to be larger when emerging-market borrowers are included in the sample, as in Panel B of Table 5, but in fact they are smaller.

- Parameter estimates for rating dummies reported in Table 7 imply that, to be the main explanation, any difference in rating agency standards across markets must vary with credit quality and, for loans to junk lenders, must be large. As shown in Table 7, for loans to investment-grade firms, the difference in spreads across markets is about 20 basis points. Because the difference from one rating dummy coefficient to the next in column 2 is not far from $20 \mathrm{bps}$, a difference in the rating agency standards implicitly would amount to about one tick on the scale. But for loans to below-investment-grade firms, the cross-market difference is about $70 \mathrm{bps}$ on average, which is approximately the difference between the coefficients on BB and B-dummies, or four ticks on the scale. We believe the latter would represent an implausibly large bias.

\subsection{Firm size, and borrower financial characteristics}

A number of hypotheses discussed previously might be invoked in support of an assertion that larger firms should pay smaller spreads, other things equal. In our pricing sample, European-market borrowers are larger on average than U.S.-market borrowers. Thus, the crossmarket price difference might be due to omission of firm size from our specifications. Loan size, 
while highly correlated with firm size in other studies, is an imperfect proxy. Only loan size is available for our full sample. However, we obtained financial statement data for as much of the 1999-2002 KMV EDF subsample as possible, including total assets, market-to-book value of assets, and measures of cash flow, profitability, and book leverage. Inclusion of a variety of combinations of such variables in the factor model does not have a material effect on the price difference across markets.

Results for one variant appear in Table 14. The left panel shows results for the base specification in this much smaller subsample. The right panel shows results when EDF and financial statement variables are included. Firm size is represented by the log of total assets, leverage by the ratio of total debt to assets, cash flow by the ratio of EBITDA to assets (ROA), and market-to-book is the ratio of (assets less book common equity plus market value of common equity) to assets. We found a materially non-linear relationship for cash flow, which is represented by dummies that correspond to each quartile plus a dummy for observations with negative ROA. Each variable is statistically significant in some specifications or subsamples, but the price difference across markets remains statistically and economically significant. The only other interesting auxiliary result not shown is that when firm size is represented by dummies for each sample quartile of total assets, first-quartile (relatively small) firms pay higher spreads, but other variations in firm size do not matter for spreads.

\subsection{Regulation}

McCauley and Seth (1992) argue that, through the early 1990s, Japanese banks had a lower cost of capital than other banks because their regulators permitted them to operate with smaller capital ratios. However, the Basel Accord harmonized capital regulation beginning in 1992. Other bank regulations differed across nations even within Europe during our sample period, so if regulations are responsible for the price differences we observe, the lender-nationality dummies used to investigate the monitoring explanation should pick them up. That is, regulation should cause lenders from a given nation to behave differently everywhere, so lender nationality should be significantly correlated with price differences. But, as noted previously, including dummy variables for lender nationality does not materially affect the explanatory power of the factor model.

A number of European banks are wholly or partly state-owned or are cooperatives. Such banks may not have profit as their primary objective and some enjoy government guarantees of their liabilities. For European banks participating in 50 or more of our sample loans, we identified those that are state-owned or cooperatives and included in regressions a dummy for any-such-banks-in-the-syndicate and a variable giving the share of such banks in the syndicate. 
Neither variable was statistically significant and the European market effect on spreads was not much affected (not shown in tables).

\subsection{Portfolio diversification effects}

The contribution of a loan to a bank's portfolio credit risk posture (equivalently, the systematic risk it bears) may affect the loan's interest rate spread in a manner that differs systematically with nationality. The conventional benchmark case in which all investors in an asset class hold the world portfolio for that class is not realistic for banks because part of their portfolios are associated with domestic small business and consumer loans originated through branch networks. ${ }^{32}$ Thus, banks tend to have large core exposures to home country credit risk, but the degree of such core exposure may differ across nations with the share of core loans in bank portfolios. Because a bank's reservation price for making a loan should depend on the extent to which the loan diversifies or concentrates its portfolio credit risk, and a borrower's nationality may affect concentration differently for different banks, spreads may differ systematically for different pairings of lender-borrower nationality. This hypothesis is difficult to test directly because banks' portfolios of credit risk positions are unobservable, but two pieces of circumstantial evidence do not support it. First, as noted previously, if the syndicated loan market is a primary vehicle for diversifying credit risk from branch-originated loans, one would expect banks to prefer foreign to domestic borrowers in the syndicated loan market, but in fact lenders display home bias.

Second, U.S. lenders should be willing to accept smaller spreads on loans made in the European market, and European lenders should accept smaller spreads in the U.S. market. However, as shown in Table 12 and discussed in section 5.2, coefficients on the fraction of lenders with each nationality interacted with the market dummy often do not differ significantly within a nationality, suggesting that lenders do not vary their hurdle rates by market. Moreover, coefficients should be smaller (more negative) for the interaction not associated with the lender's home market, but just the opposite occurs in all the cases where the difference is significant.

\subsection{Legal regime}

La Porta, Lopez-de-Silanes, Shleifer, and Vishny (1997) and others suggest that a country's legal tradition influences the nature and efficiency of its financial system. Legal tradition rather than nationality per se might drive some of the nationality-related explanations presented previously. However, when we group borrowers by the legal tradition of their country of

\footnotetext{
32 Domestic banks tend to have more branches than foreign banks because of a first-mover advantage that is at least partly due to the history of regulation.
} 
domicile (using Table 2 of La Porta et al), we find results qualitatively similar to those using our groupings of borrower nationality. 33

\subsection{Increased competition associated with evolution toward a single European market}

Santos and Tsatsaronis (2003) find substantial changes in underwriting costs borne by issuers in European bond markets as the euro came into use. They argue that reduced legal and regulatory barriers increasingly favor underwriters operating at large scale, which in turn has led to greater competition between established underwriters and new entrants as each attempts to be among the survivors. Although U.S.-based commercial and investment banks have increased their activities in the European market over the past decade, increased competition associated with European integration does not explain the fairly stable difference in investment-grade loan spreads that we observe since 1992.

\subsection{Tax and liquidity effects}

Recent empirical analyses of bond spreads, such as Elton, Gruber, Agrawal and Mann (2001) and Collin-Dufresne, Goldstein and Martin (2001) have found important roles for tax and liquidity effects as well as for unknown factors. The favorable U.S. tax treatment of interest on U.S. Treasury securities that is the primary source of most tax effects in empirical analyses of bond spreads is not relevant in our exercise, where all spreads are relative to LIBOR. Conventional noise in measured prices, due to bid-ask bounce or thin trading, is also not a problem because we use loan contract spreads. Differences across markets in the secondary market liquidity of loans are also unlikely to explain the price difference we observe: Even the relatively large loans we examine were almost completely illiquid in both markets for most of our sample period and, to the extent that secondary-market liquidity is developing, our conversations with market participants imply more rapid development in the U.S. than in Europe.

\subsection{Results with all variables included, and summary comparison}

Table 15 reports results for full-scale specifications that include variables that appear in one or more of Tables 7-13. We do not attempt to show every combination of variables reported or discussed previously. To make the presentation tractable, we display all variables from the base specification (except industry dummies), shown on the first page of Table 15. The second page reports estimates for additional non-price terms, differences in borrower and lender nationality or

\footnotetext{
33 Syndicated loan contracts often specify that either New York law or U.K. law will govern disputes among the parties to the contract, so most such disputes outside of bankruptcy will be resolved under laws in the English tradition, perhaps limiting the relevance of the borrower's home-country legal tradition. In the event of bankruptcy, most borrowers file in their home country and local legal tradition may be more relevant, but in this case, either the legal-tradition or borrower-nationality dummies should be significant, and they are not.
} 
region, fractions of syndicate lenders with each nationality, and the number of small lenders in the syndicate. Results are qualitatively similar to those reported previously, with negative and economically and statistically significant coefficients on the European market dummy variables. Panel B replaces those dummies with a set of dummies for borrower nationality within Europe. As in Table 11, what is of interest is not whether individual coefficients differ from zero (we expect that many will), but whether coefficients are similar across countries. With the caveats about Germanic and Mediterranean borrowers mentioned earlier, we cannot reject similarity, that is, it is region that matters, not nationality.

It is worth noting that we obtained results when both borrower and lender nationality dummies are included in specifications but do not display them because there is substantial apparent colinearity. When we include both sets of variables in the regressions, none are statistically significant and coefficient values are quite sensitive to small changes in specification, making the estimates rather uninformative.

Table 16 summarizes the impact that the full set of factors shown in Panel A of Table 15 has on the difference between average spreads in Europe and the U.S. Panel A of Table 16 shows simple mean differences without any controls, and panel B shows the European-market dummy coefficient estimates from the full regression model run separately for loans to borrowers in each grade. For the investment grades, differences between the U.S. and European markets grow larger with the addition of controls, not smaller. For the junk grades the changes are mixed, but point estimates change little on the whole. Results in Table 16 are also quite similar to those in Table 9, where only the base specification was used.

As noted in our discussion of Table 9, although we can reject hypotheses that average spread differences are the same in 1999-2002 as in 1992-98 for the A and B grades, we interpret the overall evidence as being consistent with no trend because test results are not very robust. For example, if we eliminate loans to A-rated borrowers originated during 2000, point estimates of differences change a little, but the p-value for the test of equality of early- and late-period spread differences changes to 0.19 .

\section{Concluding remarks}

We offer evidence that syndicated corporate loan spreads are significantly smaller in Europe than in the U.S., suggesting that a market-location factor is correlated with economically important components of the intermediation process. Systematic differences across the two markets in loan and borrower characteristics do not appear to account for the pricing difference. Importantly, nationality per se, such as borrower or lender nationality within Europe, is not 
highly correlated with spreads when controls for risk are included. The relatively small number of U.S. firms that issue in the European market pay European-market spreads, not U.S.-market spreads. These and other facts cast doubt on many potential explanations drawn from the literature on financial intermediation, including explanations focusing on differences in asymmetric information and moral hazard, creditor rights, multi-product pricing discounts, rating dynamics, and regulation. While many of our proxy variables are correlated with loan spreads, differences in spreads in the two markets remain. We also find little evidence of a trend toward convergence of spreads.

We describe the pricing difference as a puzzle because its size and persistence is suggestive of an equilibrium phenomenon (a pure failure of arbitrage on this scale by the large, sophisticated participants in the syndicated loan market is difficult to accept). Several avenues of future research might solve the puzzle and enhance understanding of corporate finance and financial intermediation.

One avenue might focus on why borrowers do not cross borders. We find that borrowers domiciled in a region that hosts a major syndicated loan market usually issue there. However, borrowers domiciled elsewhere generally choose to issue in Europe, where spreads are lower. This suggests that issuing out of home market is costly, potentially explaining why so few U.S. firms issue in Europe, which is an important element of the puzzle.

We show that lender portfolios display significant home bias. Our paper contributes to the home bias literature by revealing substantial pricing differences that appear to persist in part because of home bias. Research that reveals how home bias interferes with arbitrage by lenders, and why home bias persists in equilibrium, might also help solve our puzzle.

However, a full explanation of the loan pricing puzzle must explain not only why price differences are not competed away by lenders and borrowers, but also what causes the differences to open up. Thus, our evidence indicates that economically important aspects of financial intermediation and corporate finance remain to be discovered. That is, loans made in the European and U.S. markets may differ materially along some dimension that is relevant to price but that has received little attention. One possibility is that important mechanisms have not yet been modeled. Another is that mechanisms already in the literature work differently in Europe and the U.S. If the latter is the case, research that reveals how and why the workings of such mechanisms depend on region (but not on nationality per se) would be valuable. 


\section{References}

Angbazo, L., J.P. Mei, and A. Saunders, 1998, Highly leveraged loan transaction spreads, Journal of Banking and Finance.

Adam, Klaus, Tullio Jappelli, Annamaria Menichini, Mario Padula, and Marco Pagano, 2002, "Anayze, compare and apply alternative indicators and monitoring methodologies to measure the evolution of capital market integration in the European Union," working paper, University of Salerno.

Ammer, John, and Frank Packer, 2000, "How consistent are credit ratings: A geographic and sectoral analysis of default risk," Journal of Fixed Income 10:3, 24-30.

Ashcraft, Adam, and Don Morgan, 2003, Using loan rates to measure and regulate bank risk: Findings and an immodest proposal, Journal of Financial Services Research 24, 181-200.

Bae, Kee-Hong and VidhanK. Goyal, 2003, "Property rights protection and bank loan pricing," working paper.

Berger, Allen N, Qinglei Dai, Steven Ongena and David Smith, 2003, "To What Extent Will the Banking be Globalized? A Study of Bank Nationality and Reach in 20 European Nations," Journal of Banking and Finance 27, 383-415.

Berger, Allen N., and Gregory F. Udell, 1990, Collateral, loan quality and bank risk, Journal of Monetary Economics 25, 21-42.

Berlin, Mitchell, and Loretta J. Mester, 1992, "Debt covenants and renegotiation," Journal of Financial Intermediation 2(2), 95-133.

Boot, Arnoud W. and Anjan V. Thakor, 2000, "Can relationship banking survive competition," Journal of Finance 55(2), 679-713.

Buch, Claudia M., John C. Driscoll and Charlotte Ostergaard, 2004, Cross-border diversification in bank asset portfolios, Working paper (Washington: Federal Reserve Board), FEDS 2004-26.

Carey, Mark, Stephen Prowse, John Rea, and Gregory Udell, 1993, "The economics of the private placement market: a new look," Financial Markets, Institutions and Instruments 2:3 (Blackwell).

Carey, Mark, Steven A. Sharpe and Mitchell Post, 1998, "Does Corporate Lending by Banks and Finance Companies Differ? Evidence on Specialization in Private Debt Contracting," Journal of Finance 53, 845-78.

Casolaro, Luca, Dario Focarelli and Alberto Franco Pozzolo, 2003, The pricing effect of certification on bank loans: Evidence from the syndicated credit market, Working paper. 
Collin-Dufresne, Pierre, Robert S. Goldstein and J. Spencer Martin, 2001, The determinants of credit spread changes, Journal of Finance 51, 2177-2207.

Covitz, Daniel M., and Paul Harrison, 2003, Public debt issuance and ratings migrations: Are firms timing their issuance around temporary private information? working paper, July 2001.

Degryse, Hans, and Stephen Ongena, 2005, Distance, lending relationships and competition, Journal of Finance, forthcoming.

Dennis, Steven, and Donald Mullineaux, 2000, Syndicated loans, Journal of Financial Intermediation 9, 404-426.

Diamond, Douglas W., 1984, Financial intermediation and delegated monitoring, Review of Economic Studies 51, 393-414.

Drucker, Steven and Manju Puri, 2004, “The Tying of Lending and Equity Underwriting," working paper.

Elton, Edwin J., Martin J. Gruber, Deepak Agrawal and Christopher Mann, 2001, Explaining the rate spread on corporate bonds, Journal of Finance 56, 247-278.

Estrella, Arturo (ed.), 2000, Credit ratings and complementary sources of credit quality information, Working paper (study group report), BIS, August.

Esty, Benjamin, 2002, "When do foreign banks finance domestic investment? New evidence on the importance of legal and financial systems," working paper.

Flood, Robert P., and Andrew K. Rose, 2003, “Asset integration redux: Methodology and mystery," working paper, May 21.

James, Christopher, 1987, "Some evidence on the uniqueness of bank loans," Journal of Financial Economics 19, 217-235

Hadlock, Charles, and Christopher James, 2002, Do banks provide financial slack? Journal of Finance 57(3), 1383-1419.

Henderson, Brian J., Narasimhan Jegadeesh, and Michael S. Weisbach, 2003, “World Markets for Raising New Capital," working paper.

Houston, Joel, and Christopher James, 1996, Bank information monopolies and the mix of private and public debt claims, Journal of Finance 51, 1863-1889.

Karolyi, Andrew and Rene Stulz, 2002, “Are financial assets priced locally or globally?” Dice Center working paper 2001-11. 
La Porta, Rafael, Florencio Lopez-de-Silanes, Andrei Shleifer and Robert W. Vishny, 1997, "Legal determinants of external finance," Journal of Finance 52(3), 1131-1150.

Mahajan, Arvind, and Donald R. Fraser, 1986, Dollar Eurobond pricing and U.S. bond pricing, Journal of International Business Studies 17, 21-37.

McCauley, Robret N. and Rama Seth, 1992, "Foreign bank credit to US corporations: the implications of offshore loans," Federal Reserve Bank of New York Quarterly Review 17, Spring.

Merton, Robert, 1974, On the pricing of corporate debt: The risk structure of interest rates, Journal of Finance 29, 449-470.

Moody's Investors Service, 2003, Special comment: Recovery rates on defaulted corporate bonds and preferred stocks, 1982-2003 (New York).

Petersen, Mitchell, and Raghuram Rajan, 2002, "Does distance still matter: The information revolution in small business lending," Journal of Finance 57, 2533-2570.

Rajan, Raghuram, 1992, “Insiders and outsiders: the choice between informed and arm's-length debt," Journal of Finance 47, 1367-1400.

Santos, Joao and Kostas Tsatsaronis, 2003, "The cost of barriers to entry: evidence from the market for corporate euro bond underwriting," BIS working paper No. 134.

Smith, C. and J. Warner, 1979, "On financial contracting: an analysis of bond covenants," Journal of Financial Economics, 117-161. 


\section{Table 1. Relationship of market region and borrower domicile}

Data are for all multi-lender loans reported in Loanware as made in the three markets during 1992-2002. Panel A examines the composition of each market in terms of borrower domicile, whereas Panel B examines the market choices of borrowers from each domicile, one at a time.

\section{Panel A. Percentage of syndicated loan volume in each market due to borrowers in} each domicile

\begin{tabular}{|lccc|}
\hline \multicolumn{1}{|c}{ Borrower domicile } & U.S. market & European market & $\begin{array}{c}\text { Asian \& SW } \\
\text { Pacific market }\end{array}$ \\
\hline United States & 97.7 & 3.2 & 2.6 \\
Europe & 0.5 & 81.8 & 1.0 \\
Latin America & 0.2 & 6.3 & 0.3 \\
Canada & 1.0 & 0.6 & 0.0 \\
Asia \& SW Pacific & 0.1 & 1.9 & 94.4 \\
Other & 0.5 & 6.2 & 1.7 \\
Total & 100.0 & 100.0 & 100.0 \\
\hline
\end{tabular}

Panel B. Percentage of syndicated loan volume issued by borrowers in each domicile appearing in each market

\begin{tabular}{|lcccc|}
\hline \multicolumn{1}{r}{ Borrower domicile } & & \multicolumn{3}{c|}{ Asian \& SW } \\
United States & U.S. market & European market & Pacific market & Total \\
Europe & 98.5 & 1.2 & 0.3 & 100.0 \\
Latin America & 1.7 & 98.0 & 0.3 & 100.0 \\
Canada & 6.0 & 93.0 & 1.0 & 100.0 \\
Asia \& SW Pacific & 80.5 & 19.4 & 0.1 & 100.0 \\
Other & 0.9 & 6.9 & 92.2 & 100.0 \\
\hline
\end{tabular}

Table 2. Out-of-market-lender share of loans in each market

Data are for all multi-lender loans reported in Loanware as made in the three markets during 1992-2002 that include information about participating lenders' shares of the amount of the loan. Results are similar if loans for which shares are missing are included by assuming each lender takes an equal share.

\begin{tabular}{|l|cc|c|c|c|}
\hline & \multicolumn{2}{|c|}{$\begin{array}{c}\text { Percentage of lenders from } \\
\text { outside the market }\end{array}$} & $\begin{array}{c}\text { Percentage of lead lenders } \\
\text { from outside the market }\end{array}$ & $\begin{array}{c}\text { Number of lenders } \\
\text { in syndicate }\end{array}$ \\
\hline Market & By volume & By number & By number & Median & Mean \\
\cline { 2 - 7 } U.S. & 29 & 21 & 12 & 4 & 8 \\
Europe & 23 & 20 & 19 & 8 & 11 \\
Asia & 21 & 19 & 17 & 7 & 9 \\
\hline
\end{tabular}




\section{Table 3. Home bias: Portfolio allocations of lenders in each region.}

Data are for all multi-lender loans reported in Loanware as made in the three markets during 1992-2002 that include information about participating lenders' shares of the amount of the loan. If loans with missing shares are included, results are similar, except that lenders from the Other region have shares of 40, 14 and 46 percent in loans to U.S., European and other borrowers, respectively (for loans without share data, we assume each lender takes an equal share).

\begin{tabular}{|l|ccc|c|}
\hline & \multicolumn{3}{|c|}{ Lender region } & Global \\
Borrower region & US & Europe & Other & weight \\
\cline { 2 - 4 } & 91 & 39 & 31 & 64 \\
ES & 6 & 51 & 12 & 22 \\
Other & 3 & 10 & 57 & 14 \\
Total & 100 & 100 & 100 & 100 \\
Memo: Lender- & & & & \\
region share & 49 & 35 & 16 & \\
\hline
\end{tabular}

\section{Table 4. Distribution of borrowers by rating}

Data are for all multi-lender loans reported in Loanware as made in the three markets during 1992-2002 and that have a rating reported in Loanware, or a rating we were able to locate by matching to Moody's DRS database. However, all loans are in the denominator of the measures in the Memo line. Ratings are the riskier of Moody's and S\&P ratings when both are available and are as of the loan contract date. Values are percentages of total loan volume.

\begin{tabular}{|lcc|}
\hline \multirow{2}{*}{ Rating } & \multicolumn{2}{c|}{ Market } \\
\cline { 2 - 3 } Investment grade (percent) & $\mathbf{U 3}$ & European \\
AAA and AA & 9 & $\mathbf{8 8}$ \\
A & 35 & 43 \\
BBB & 28 & 25 \\
Speculative grade (percent) & $\mathbf{2 7}$ & $\mathbf{1 2}$ \\
BB & 14 & 7 \\
B & 12 & 6 \\
Less than B & 1 & 0 \\
Memo: Percent of total volume & 66 & 40 \\
by unrated borrowers & & \\
\hline
\end{tabular}




\section{Table 5. Mean spreads by grade and market (basis points)}

The sample is restricted to loans to borrowers for which a rating is available on the date the loan contract is signed. Ratings are the riskier of Moody's and S\&P's rating if both are available. Spreads are all-in measures that include the contract spread on outstanding balances plus annual fee plus any upfront fee prorated over the original term to maturity of the loan. Fixed-rate loans, loans with no spread information, notes, and loans with purposes ESOP, debtor-in-possession, and private placements are excluded.

\begin{tabular}{|c|ccc|ccc|}
\hline & \multicolumn{2}{|c|}{$\begin{array}{c}\text { Panel A. } \\
\text { industrialized nations only }\end{array}$} & \multicolumn{3}{c|}{$\begin{array}{c}\text { Banel B. Borrowers from } \\
\text { all nations }\end{array}$} \\
\cline { 2 - 7 } Rating & $\begin{array}{c}\text { U.S. } \\
\text { market }\end{array}$ & $\begin{array}{c}\text { European } \\
\text { market }\end{array}$ & Difference & $\begin{array}{c}\text { U.S. } \\
\text { market }\end{array}$ & $\begin{array}{c}\text { European } \\
\text { market }\end{array}$ & Difference \\
\hline AA & 30 & 32 & -2 & 31 & 31 & 0 \\
A & 44 & 40 & 4 & 44 & 41 & 3 \\
BBB & 92 & 65 & 27 & 92 & 78 & 14 \\
BB & 182 & 128 & 54 & 186 & 152 & 34 \\
B & 255 & 189 & 66 & 249 & 204 & 45 \\
\hline
\end{tabular}

\section{Table 6. Some nonprice terms of syndicated loans and borrower characteristics}

Data for the full sample are for all multi-lender loans reported in Loanware as made in the three markets during 1992-2002. Data for the regression sample are restricted to loans to borrowers in industrialized nations and for which ratings and spreads at issuance are available. Fixed-rate loans, notes, and loans with purposes ESOP, debtorin-possession, and private placements are excluded from both samples.

\begin{tabular}{|c|c|c|c|c|}
\hline \multirow[b]{2}{*}{ Loan or borrower characteristic } & \multicolumn{2}{|c|}{ A: Full sample } & \multicolumn{2}{|c|}{ B: Regression sample } \\
\hline & $\begin{array}{c}\text { U.S. } \\
\text { market }\end{array}$ & $\begin{array}{c}\text { European } \\
\text { market }\end{array}$ & $\begin{array}{c}\text { U.S. } \\
\text { market }\end{array}$ & $\begin{array}{c}\text { European } \\
\text { market }\end{array}$ \\
\hline Number of usable observations & 34345 & 13783 & 10590 & 852 \\
\hline Median term to maturity (months) & 46 & 63 & 46 & 55 \\
\hline Median loan size (\$millions) & 147 & 125 & 316 & 417 \\
\hline Mean loan size (\$millions) & 370 & 340 & 672 & 983 \\
\hline Percent lines of credit & 64 & 35 & 71 & 67 \\
\hline Percent secured & 31 & 26 & 32 & 13 \\
\hline Stated purpose of loan (percent) & & & & \\
\hline General corporate purposes & 83 & 65 & 80 & 69 \\
\hline Takeover, acquisition, recap & 3 & 1 & 3 & 2 \\
\hline Project finance & 2 & 17 & 1 & 3 \\
\hline Ships, aircraft, or SPVs & 2 & 10 & 1 & 7 \\
\hline Backup line & 10 & 7 & 15 & 19 \\
\hline Type of borrower (percent) & & & & \\
\hline Non-financial firms & 86 & 79 & 89 & 74 \\
\hline Government-affiliated & 1 & 17 & 1 & 13 \\
\hline
\end{tabular}


Table 7. Base factor model specification

The dependent variable in OLS regressions is the all-in spread on outstanding loan balances. Coefficients of particular interest are those on the "European market" dummies (which indicate loans issued there). All independent variables are dummies except the log of loan size. Rating migrations are measured from the loan contract date to one year after the contract date. Only loans to borrowers rated A+ or riskier and B- or better on the loan contract date are included. "Investment Grade" is A+ to BBB- in this context. "Junk Grades" are BB+ to B-.

\begin{tabular}{|c|c|c|c|c|c|c|}
\hline \multirow[b]{2}{*}{ Independent variable } & \multicolumn{2}{|c|}{ (1) All Grades } & \multicolumn{2}{|c|}{ (2) Investment Grade } & \multicolumn{2}{|c|}{ (3) Junk Grades } \\
\hline & Coefficient & P-value & Coefficient & P-value & Coefficient & P-value \\
\hline Intercept & 82.20 & $<.0001$ & 77.19 & $<.0001$ & 172.62 & $<.0001$ \\
\hline European market 1992-98 & -20.51 & $<.0001$ & -20.26 & $<.0001$ & -50.06 & $<.0001$ \\
\hline European market 1999-02 & -41.54 & $<.0001$ & -16.05 & $<.0001$ & -85.14 & $<.0001$ \\
\hline H0: $1992-98=1999-02$ & & $<.0001$ & & 0.126 & & 0.0007 \\
\hline Year=1993 & -1.40 & 0.6902 & -7.23 & 0.0485 & 2.87 & 0.5908 \\
\hline Year=1994 & -16.55 & $<.0001$ & -16.05 & $<.0001$ & -17.74 & 0.0008 \\
\hline Year=1995 & -18.49 & $<.0001$ & -21.01 & $<.0001$ & -16.74 & 0.0021 \\
\hline Year $=1996$ & -22.46 & $<.0001$ & -21.77 & $<.0001$ & -20.73 & 0.0001 \\
\hline Year $=1997$ & -29.90 & $<.0001$ & -27.66 & $<.0001$ & -29.69 & $<.0001$ \\
\hline Year $=1998$ & -10.85 & 0.0012 & -10.46 & 0.003 & -7.84 & 0.1181 \\
\hline Year=1999 & 22.02 & $<.0001$ & 5.83 & 0.0882 & 33.28 & $<.0001$ \\
\hline Year $=2000$ & 35.96 & $<.0001$ & 9.68 & 0.004 & 60.28 & $<.0001$ \\
\hline Year=2001 & 38.31 & $<.0001$ & 11.02 & 0.001 & 69.59 & $<.0001$ \\
\hline Year=2002 & 44.57 & $<.0001$ & 6.74 & 0.0454 & 87.74 & $<.0001$ \\
\hline Borrower rated $\mathrm{A}$ & -2.60 & 0.4063 & 0.01 & 0.9951 & & \\
\hline Borrower rated A- & 4.42 & 0.1669 & 7.68 & 0.0003 & & \\
\hline Borrower rated $\mathrm{BBB}+$ & 15.03 & $<.0001$ & 22.03 & $<.0001$ & & \\
\hline Borrower rated BBB & 30.84 & $<.0001$ & 38.57 & $<.0001$ & & \\
\hline Borrower rated BBB- & 50.12 & $<.0001$ & 58.33 & $<.0001$ & & \\
\hline Borrower rated BB+ & 76.10 & $<.0001$ & & & & \\
\hline Borrower rated BB & 115.79 & $<.0001$ & & & 37.84 & $<.0001$ \\
\hline Borrower rated BB- & 135.53 & $<.0001$ & & & 54.53 & $<.0001$ \\
\hline Borrower rated B+ & 166.53 & $<.0001$ & & & 82.98 & $<.0001$ \\
\hline Borrower rated B & 177.09 & $<.0001$ & & & 90.14 & $<.0001$ \\
\hline Borrower rated B- & 184.16 & $<.0001$ & & & 101.93 & $<.0001$ \\
\hline No migration information & 2.94 & 0.0254 & 10.03 & $<.0001$ & -3.94 & 0.0652 \\
\hline Rating worsens 1 tick & 9.13 & 0.0002 & 2.37 & 0.3236 & 13.99 & 0.0006 \\
\hline Rating wo & 17.78 & $<.0001$ & 19.89 & $<.0001$ & 17.40 & 0.0011 \\
\hline Rating worsens 4 or more ticks & 38.48 & $<.0001$ & 23.54 & $<.0001$ & 59.74 & $<.0001$ \\
\hline Rating improves 1 tick & -16.32 & $<.0001$ & -13.24 & 0.0004 & -20.10 & $<.0001$ \\
\hline Rating improves 2 or 3 ticks & -10.19 & 0.0826 & -27.34 & 0.0018 & -4.03 & 0.5998 \\
\hline Rating improves 4 or more ticks & -27.25 & 0.0172 & -7.06 & 0.5661 & -43.48 & 0.0101 \\
\hline Log loan size & -8.11 & $<.0001$ & -4.82 & $<.0001$ & -13.27 & $<.0001$ \\
\hline Term loan & 45.83 & $<.0001$ & 40.34 & $<.0001$ & 42.18 & $<.0001$ \\
\hline Bridge or unknown loan type & 9.19 & 0.0004 & 4.85 & 0.0688 & 15.84 & $<.0001$ \\
\hline Takeover loan & 15.79 & $<.0001$ & 15.04 & 0.0419 & 19.16 & 0.0001 \\
\hline Ship, plane or SPV finance & -0.37 & 0.949 & 11.98 & 0.0076 & -27.66 & 0.0342 \\
\hline Project finance loan & -19.53 & 0.012 & 2.63 & 0.7602 & -25.48 & 0.0273 \\
\hline CP backup loan & -12.92 & $<.0001$ & -7.76 & $<.0001$ & -40.83 & $<.0001$ \\
\hline Have loan fee info & 15.18 & $<.0001$ & 13.40 & $<.0001$ & 28.54 & $<.0001$ \\
\hline Multi-entity obligor & 7.39 & 0.0109 & 7.28 & 0.0125 & 9.18 & 0.043 \\
\hline \multicolumn{7}{|c|}{ Industry dummies included but omitted to save space } \\
\hline Adjusted $R^{2}$ & 0.700 & & 0.437 & & 0.463 & \\
\hline Number of observations & 11441 & & 5395 & & 6045 & \\
\hline
\end{tabular}


Table 8. Base case factor model augmented with maturity, seniority, amortization

The dependent variable in OLS regressions is the all-in spread on outstanding loan balances. The specification and data are identical to the base specification reported in Table 7 apart from the addition of variables shown at the bottom of the table (Bullet loan through Maturity more than six years). A bullet loan is one for which no principal is due before maturity.

\begin{tabular}{|c|c|c|c|c|}
\hline \multirow[b]{2}{*}{ Independent variable } & \multicolumn{2}{|c|}{ (1) Investment Grade } & \multicolumn{2}{|c|}{ (2) Junk Grades } \\
\hline & Coefficient & P-value & Coefficient & P-value \\
\hline Intercept & 67.81 & $<.0001$ & 153.56 & $<.0001$ \\
\hline European market 1992-98 & -25.08 & $<.0001$ & -45.21 & $<.0001$ \\
\hline European market 1999-02 & -18.31 & $<.0001$ & -80.82 & $<.0001$ \\
\hline Year=1993 & -5.34 & 0.1338 & 3.73 & 0.4783 \\
\hline Year=1994 & -15.80 & $<.0001$ & -18.11 & 0.0005 \\
\hline Year=1995 & -21.45 & $<.0001$ & -16.56 & 0.002 \\
\hline Year=1996 & -23.79 & $<.0001$ & -22.23 & $<.0001$ \\
\hline Year $=1997$ & -27.24 & $<.0001$ & -28.24 & $<.0001$ \\
\hline Year=1998 & -8.93 & 0.0099 & -8.30 & 0.0946 \\
\hline Year=1999 & 8.56 & 0.0121 & 33.10 & $<.0001$ \\
\hline Year $=2000$ & 13.56 & $<.0001$ & 62.08 & $<.0001$ \\
\hline Year=2001 & 16.09 & $<.0001$ & 71.81 & $<.0001$ \\
\hline Year=2002 & 9.67 & 0.0043 & 90.89 & $<.0001$ \\
\hline Borrower rated $A$ & 0.13 & 0.95 & & \\
\hline Borrower rated A- & 7.60 & 0.0003 & & \\
\hline Borrower rated $\mathrm{BBB}+$ & 21.05 & $<.0001$ & & \\
\hline Borrower rated BBB & 37.51 & $<.0001$ & & \\
\hline Borrower rated BBB- & 55.38 & $<.0001$ & & \\
\hline Borrower rated BB+ & & & & \\
\hline Borrower rated BB & & & 32.65 & $<.0001$ \\
\hline Borrower rated BB- & & & 45.01 & $<.0001$ \\
\hline Borrower rated $\mathrm{B}+$ & & & 71.46 & $<.0001$ \\
\hline Borrower rated B & & & 79.50 & $<.0001$ \\
\hline Borrower rated B- & & & 90.28 & $<.0001$ \\
\hline No migration info & 9.54 & $<.0001$ & -1.86 & 0.3765 \\
\hline Rating worsens 1 tick & 2.72 & 0.241 & 15.20 & 0.0002 \\
\hline Rating worsens 2 or 3 ticks & 17.15 & $<.0001$ & 19.15 & 0.0003 \\
\hline Rating worsens 4 or more ticks & 21.25 & $<.0001$ & 63.25 & $<.0001$ \\
\hline Rating improves 1 tick & -13.46 & 0.0002 & -19.63 & $<.0001$ \\
\hline Rating improves 2 or 3 ticks & -30.10 & 0.0004 & -1.16 & 0.878 \\
\hline Rating improves 4 or more ticks & -7.14 & 0.5494 & -32.36 & 0.0512 \\
\hline Log loan size & -3.89 & $<.0001$ & -13.29 & $<.0001$ \\
\hline Term loan & 32.16 & $<.0001$ & 35.84 & $<.0001$ \\
\hline Bridge or unknown type loan & 1.57 & 0.556 & 17.53 & $<.0001$ \\
\hline Takeover loan & 9.23 & 0.1981 & 14.10 & 0.0038 \\
\hline Ship, plane or SPV finance & 0.91 & 0.8361 & -30.08 & 0.0189 \\
\hline Project finance loan & -25.50 & 0.0028 & -41.34 & 0.0003 \\
\hline CP backup loan & -6.06 & $<.0001$ & -32.34 & 0.0014 \\
\hline Have loan fee info & 12.26 & $<.0001$ & 26.83 & $<.0001$ \\
\hline Multi-entity obligor & 4.01 & 0.16 & 5.51 & 0.2159 \\
\hline Bullet loan & -2.84 & 0.0874 & -0.25 & 0.93 \\
\hline Guarantee present & 14.26 & $<.0001$ & -2.12 & 0.676 \\
\hline Secured & 29.39 & $<.0001$ & 23.82 & $<.0001$ \\
\hline Maturity 1 to 3 years & 8.40 & $<.0001$ & 18.90 & $<.0001$ \\
\hline Maturity 3 to 6 years & 2.03 & 0.1404 & 10.99 & 0.0069 \\
\hline Maturity more than six years & 25.72 & $<.0001$ & 29.36 & $<.0001$ \\
\hline Adjusted $\mathrm{R}^{2}$ & 0.471 & & 0.485 & \\
\hline Number observations & 5395 & & 6045 & \\
\hline
\end{tabular}


Table 9. Results from regressions for separate grades, by period, and for trend.

This table shows results from regressions using the full base specification displayed in Table 7, but run separately for loans to borrowers in each grade. Only estimates for the variables interacting market and time period are displayed to save space. The far right column reports results of a test of the hypothesis that coefficients for the early and late time periods are the same.

\begin{tabular}{|lrrrrrrr|}
\hline & \multicolumn{3}{c|}{ A: Europe 1992-98 } & \multicolumn{5}{c|}{ B: Europe 1999-2002 } \\
Rating & Coefficient Std Error & P: Coef=0 & Coefficient & Std Error & P: Coef=0 & P: A=B \\
\hline A & -16.97 & 2.10 & $<.0001$ & -5.75 & 2.65 & 0.0302 & 0.0003 \\
BBB & -35.94 & 5.57 & $<.0001$ & -24.80 & 5.00 & $<.0001$ & 0.1171 \\
BB & -43.19 & 10.43 & $<.0001$ & -62.89 & 13.44 & $<.0001$ & 0.2265 \\
B & -55.05 & 10.58 & $<.0001$ & -101.05 & 13.04 & $<.0001$ & 0.0058 \\
\hline
\end{tabular}

\section{Table 10. Number of European-market pricing-sample observations by country of borrower.}

Data are from the regression sample, which is restricted to loans to borrowers in industrialized nations and for which ratings and spreads at issuance are available. Fixed-rate loans, loans with no spread information, notes, and loans with purposes ESOP, debtor-in-possession, and private placements are excluded.

\begin{tabular}{|lrrrrr|}
\hline & \multicolumn{4}{c}{$1992-1998$} & \multicolumn{2}{c|}{$1999-2002$} \\
Country & Overall & Inv. Grade & Junk & Inv. Grade & Junk \\
\hline UK. & 408 & 202 & 27 & 135 & 44 \\
Germanic & 41 & 10 & 4 & 25 & 2 \\
French & 76 & 46 & 3 & 24 & 3 \\
Nordic & 126 & 71 & 6 & 35 & 14 \\
Mediterranean & 60 & 42 & 5 & 5 & 8 \\
U.S. & 102 & 40 & 51 & 9 & 2 \\
Rest of world & 39 & 25 & 3 & 10 & 1 \\
Total European market & 852 & 436 & 99 & 243 & 74 \\
Memo: Total U.S. market & 10590 & 2233 & 3292 & 2484 & 2581 \\
\hline
\end{tabular}


Table 11. Base-case factor model augmented with country-of-borrower dummies.

The dependent variable in OLS regressions is the all-in spread on outstanding loan balances. The specification and data are identical to the base specification reported in Table 7 apart from the addition of variables following the "Borrower nationality dummies" subheading. Loan size, loan type, loan purpose, fee information, and multi-entity obligor dummies are included in the regressions but not shown.

\begin{tabular}{|c|c|c|c|c|}
\hline \multirow[b]{2}{*}{ Independent variable } & \multicolumn{2}{|c|}{ (1) Investment grade } & \multicolumn{2}{|c|}{ (2) Junk } \\
\hline & Coefficient & P-value & Coefficient & P-value \\
\hline Intercept & 77.87 & $<.0001$ & 173.34 & 0.5416 \\
\hline European market 1992-98 & & & & \\
\hline European market 1999-02 & & & & \\
\hline Year=1993 & -7.80 & 0.0331 & 3.25 & 0.5416 \\
\hline Year=1994 & -15.34 & $<.0001$ & -17.18 & 0.0011 \\
\hline Year $=1995$ & -20.55 & $<.0001$ & -16.95 & 0.0018 \\
\hline Year=1996 & -21.32 & $<.0001$ & -20.82 & 0.0001 \\
\hline Year $=1997$ & -27.59 & $<.0001$ & -30.07 & $<.0001$ \\
\hline Year=1998 & -10.68 & 0.0024 & -8.69 & 0.0835 \\
\hline Year=1999 & 6.21 & 0.0686 & 33.08 & $<.0001$ \\
\hline Year $=2000$ & 9.70 & 0.0038 & 60.09 & $<.0001$ \\
\hline Year $=2001$ & 11.31 & 0.0007 & 69.15 & $<.0001$ \\
\hline Year=2002 & 6.83 & 0.0423 & 87.04 & $<.0001$ \\
\hline Borrower rated $\mathrm{A}$ & -0.63 & 0.7613 & 37.89 & $<.0001$ \\
\hline Borrower rated A- & 7.09 & 0.0009 & 54.82 & $<.0001$ \\
\hline Borrower rated $\mathrm{BBB}+$ & 21.71 & $<.0001$ & 83.06 & $<.0001$ \\
\hline Borrower rated BBB & 38.41 & $<.0001$ & 90.68 & $<.0001$ \\
\hline Borrower ra & 58.95 & $<.0001$ & 101.88 & $<.0001$ \\
\hline Borrower rated BB+ & 10.50 & $<.0001$ & -4.22 & 0.0488 \\
\hline Borrower rated BB & 2.44 & 0.3061 & 14.09 & 0.0006 \\
\hline Borrower rated BB- & 19.42 & $<.0001$ & 17.48 & 0.0011 \\
\hline Borrower rated B+ & 23.17 & $<.0001$ & 59.73 & $<.0001$ \\
\hline Borrower rated B & -13.51 & 0.0003 & -19.59 & $<.0001$ \\
\hline Borrower rated B- & -27.05 & 0.002 & -4.22 & 0.582 \\
\hline No migration info & -7.22 & 0.5545 & -43.76 & 0.0096 \\
\hline Rating worsens 1 tick & -5.03 & $<.0001$ & -13.35 & $<.0001$ \\
\hline Rating worsens 2 or 3 ticks & 43.28 & $<.0001$ & 42.35 & $<.0001$ \\
\hline Rating worsens 4 or more ticks & 4.81 & 0.0695 & 15.63 & $<.0001$ \\
\hline Rating improves 1 tick & 13.46 & 0.0671 & 19.16 & 0.0001 \\
\hline Rating imp & 10.87 & 0.0152 & -22.30 & 0.0948 \\
\hline Rating improves 4 or more ticks & 0.17 & 0.9841 & -24.59 & 0.0338 \\
\hline \multicolumn{5}{|c|}{ Borrower nationality dummies:(some other vari } \\
\hline UK, 92-98 & -16.51 & $<.0001$ & -18.12 & 0.1983 \\
\hline UK, 99-02 & -13.05 & 0.0004 & -81.41 & $<.0001$ \\
\hline Germanic, 92-98 & 6.16 & 0.6338 & -55.69 & 0.1205 \\
\hline Germanic & -26.38 & 0.0015 & 83.07 & 0.101 \\
\hline Nordic, 92-98 & -25.83 & $<.0001$ & -61.29 & $0.03 \varepsilon$ \\
\hline Nordic, 99-02 & -13.88 & 0.051 & -110.07 & $<.000$ \\
\hline French, 92-98 & -22.59 & 0.0008 & -30.48 & 0.4596 \\
\hline French, 99-02 & -19.85 & 0.0181 & -176.38 & $<.0001$ \\
\hline Mediterranean, 92-98 & -76.79 & $<.0001$ & -64.01 & 0.0468 \\
\hline Mediterranean, 99-02 & -35.00 & 0.0553 & -82.45 & 0.022 \\
\hline U.S., 92-98 & -17.87 & 0.0059 & -69.03 & $<.0001$ \\
\hline U.S., 99-02 & -10.76 & 0.425 & -41.54 & 0.4106 \\
\hline Rest of world, 92-98 & -34.17 & $<.0001$ & 6.30 & 0.879 \\
\hline Rest of world, 99-02 & -62.62 & $<.0001$ & -146.51 & 0.043 \\
\hline Adjusted $\mathrm{R}^{2}$ & 0.444 & & 0.464 & \\
\hline Number observations & 5395 & & 6045 & \\
\hline
\end{tabular}


Table 12. Base-case factor model augmented with share of lenders by nationality

The dependent variable in OLS regressions is the all-in spread on outstanding loan balances. The specification and data are identical to the base specification reported in Table 7 apart from the addition of variables following the "Fraction of lenders with each nationality" subheading. Panel A includes all lenders in a syndicate in computing fractions whereas Panel B includes only lead lenders. Loan size, loan type, loan purpose, fee information, and multi-entity obligor dummies are included in the regressions but not shown to save space.

\begin{tabular}{|c|c|c|c|c|c|c|c|c|}
\hline \multirow[b]{3}{*}{ Independent variable } & \multicolumn{4}{|c|}{ A: Lender variables: fraction all lenders } & \multicolumn{4}{|c|}{ B: Lender variables: fraction lead lenders } \\
\hline & \multicolumn{2}{|c|}{ Investment Grade } & \multicolumn{2}{|c|}{ Junk } & \multicolumn{2}{|c|}{ Investment Grade } & \multicolumn{2}{|c|}{ Junk } \\
\hline & Coeff. & P-value & Coeff. & P-value & Coeff. & $P$-value & Coeff. & P-value \\
\hline Intercept & 76.84 & $<.0001$ & 175.75 & $<.0001$ & 77.01 & $<.0001$ & 171.79 & $<.0001$ \\
\hline European market 1992-98 & -18.25 & $<.0001$ & -51.87 & $<.0001$ & -20.49 & $<.0001$ & -51.13 & $<.0001$ \\
\hline European market 1999-02 & -14.03 & $<.0001$ & -86.61 & $<.0001$ & -17.95 & $<.0001$ & -87.67 & $<.0001$ \\
\hline Year $=1993$ & -7.59 & 0.0388 & 2.53 & 0.6347 & -6.95 & 0.0585 & 2.86 & 0.5911 \\
\hline Year $=1994$ & -16.12 & $<.0001$ & -18.53 & 0.0004 & -15.50 & $<.0001$ & -17.55 & 0.0009 \\
\hline Year $=1995$ & -21.46 & $<.0001$ & -18.58 & 0.0006 & -20.40 & $<.0001$ & -16.53 & 0.0023 \\
\hline Year=1996 & -21.85 & $<.0001$ & -21.16 & $<.0001$ & -21.29 & $<.0001$ & -20.76 & 0.0001 \\
\hline Year $=1997$ & -27.51 & $<.0001$ & -30.70 & $<.0001$ & -27.33 & $<.0001$ & -29.49 & $<.0001$ \\
\hline Year $=1998$ & -9.81 & 0.0054 & -9.96 & 0.0477 & -10.09 & 0.0042 & -7.84 & 0.1189 \\
\hline Year $=1999$ & 6.49 & 0.0587 & 29.74 & $<.0001$ & 6.01 & 0.0788 & 33.28 & $<.0001$ \\
\hline Year $=2000$ & 10.07 & 0.0029 & 56.68 & $<.0001$ & 9.94 & 0.0031 & 60.22 & $<.0001$ \\
\hline Year=2001 & 11.51 & 0.0006 & 65.75 & $<.0001$ & 11.78 & 0.0005 & 69.18 & $<.0001$ \\
\hline Year=2002 & 6.76 & 0.0463 & 81.99 & $<.0001$ & 7.29 & 0.0312 & 87.29 & $<.0001$ \\
\hline Borrower rated A & -0.55 & 0.7936 & & & 0.13 & 0.9512 & & \\
\hline Borrower rated A- & 6.77 & 0.0016 & & & 7.48 & 0.0005 & & \\
\hline Borrower rated $\mathrm{BBB}+$ & 21.27 & $<.0001$ & & & 21.88 & $<.0001$ & & \\
\hline Borrower rated BBB & 37.58 & $<.0001$ & & & 38.51 & $<.0001$ & & \\
\hline $\begin{array}{l}\text { Borrower rated BBB- } \\
\text { Borrower rated BB+ }\end{array}$ & 57.21 & $<.0001$ & & & 58.41 & $<.0001$ & & \\
\hline Borrower rated BB & & & 37.51 & $<.0001$ & & & 38.44 & $<.0001$ \\
\hline Borrow & & & 54.35 & $<.0001$ & & & 55.10 & $<.0001$ \\
\hline Borron & & & 82.34 & $<.0001$ & & & 83.37 & $<.0001$ \\
\hline Borrower rated B & & & 89.07 & $<.0001$ & & & 90.49 & $<.0001$ \\
\hline Borrower rated B- & & & 100.51 & $<.0001$ & & & 102.63 & $<.0001$ \\
\hline No mi & 10.12 & $<.0001$ & -3.74 & 0.0796 & 9.99 & $<.0001$ & -3.66 & 0.087 \\
\hline Rating wc & 2.34 & 0.3284 & 13.92 & 0.0007 & 2.09 & 0.3821 & 13.96 & 0.0007 \\
\hline Rating worsens 2 or 3 & 19.49 & $<.0001$ & 17.33 & 0.0012 & 19.57 & $<.0001$ & 17.24 & 0.0013 \\
\hline more & 22.92 & $<.0001$ & 59.96 & $<.0001$ & 23.25 & $<.0001$ & 59.06 & $<.0001$ \\
\hline Rating improves 1 tick & -13.10 & 0.0004 & -19.76 & $<.0001$ & -13.30 & 0.0003 & -20.17 & $<.0001$ \\
\hline Rating improves 2 or 3 & -27.23 & 0.0018 & -4.92 & 0.5207 & -27.40 & 0.0017 & -4.46 & 0.5612 \\
\hline Rating improves 4 or more & -7.13 & 0.5615 & -42.56 & 0.0116 & -7.21 & 0.5572 & -44.64 & 0.0083 \\
\hline \multicolumn{9}{|c|}{ Fraction of lenders with each nationality (U.S. is omitted category; some other variables not shown) } \\
\hline UK & -2.61 & 0.7067 & 0.26 & 0.9845 & 1.95 & 0.5974 & 3.68 & 0.7064 \\
\hline Medite & -56.63 & $<.0001$ & -23.61 & 0.4958 & -37.06 & 0.0365 & 29.79 & 0.6098 \\
\hline Frencl & 4.92 & 0.4057 & 13.81 & 0.1743 & 9.00 & 0.0954 & -2.70 & 0.711 \\
\hline Germanic & -5.40 & 0.2747 & 16.50 & 0.0757 & 2.28 & 0.4925 & 12.83 & 0.0847 \\
\hline Nordic & 0.11 & 0.9894 & -4.86 & 0.735 & -4.53 & 0.4308 & -26.78 & 0.0076 \\
\hline Japanese & -4.27 & 0.4304 & -48.91 & $<.0001$ & -23.84 & 0.0001 & 27.03 & 0.1302 \\
\hline Rest of World (non-U.S.) & 2.55 & 0.6188 & -33.17 & $<.0001$ & 0.78 & 0.8402 & 7.67 & 0.1214 \\
\hline Adjusted R2 & 0.439 & & 0.466 & & 0.439 & & 0.463 & \\
\hline Number observations & 5395 & & 6045 & & 5393 & & 6044 & \\
\hline
\end{tabular}




\section{Table 13. Base-case factor model augmented with syndicate size variables}

The dependent variable in OLS regressions is the all-in spread on outstanding loan balances. The specification and data are identical to the base specification reported in Table 7 apart from the addition of variables following the "Syndicate size variables" subheading. Panel A includes variables measuring the number of lenders in a syndicate, whereas panel B includes variables measuring only the number of small lenders. "Small" is defined as those which Loanware records as participating in less than 1000 loans during 1992-2002. Loan size, loan type, loan purpose, fee information, and multi-entity obligor dummies are included in the regressions but not shown to save space.

\begin{tabular}{|c|c|c|c|c|c|c|c|c|}
\hline \multirow[b]{3}{*}{ Independent variable } & \multicolumn{4}{|c|}{ A: Syndicate size } & \multicolumn{4}{|c|}{ B: Syndicate composition: small lenders } \\
\hline & \multicolumn{2}{|c|}{ Investment Grade } & \multicolumn{2}{|c|}{ Junk } & \multicolumn{2}{|c|}{ Investment Grade } & \multicolumn{2}{|c|}{ Junk } \\
\hline & Coeff. & P-value & Coeff. & P-value & Coeff. & P-value & Coeff. & P-value \\
\hline Intercept & 82.57 & $<.0001$ & 177.61 & $<.0001$ & 78.42 & $<.0001$ & 180.47 & $<.0001$ \\
\hline European market 1992-98 & -20.44 & $<.0001$ & -49.20 & $<.0001$ & -20.83 & $<.0001$ & -50.64 & $<.0001$ \\
\hline European market 1999-02 & -16.88 & $<.0001$ & -84.94 & $<.0001$ & -17.67 & $<.0001$ & -84.58 & $<.0001$ \\
\hline Year $=1993$ & -7.57 & 0.0389 & 3.67 & 0.4908 & -7.77 & 0.0339 & 2.92 & 0.5812 \\
\hline Year=1994 & -15.88 & $<.0001$ & -16.53 & 0.0017 & -16.02 & $<.0001$ & -17.06 & 0.0011 \\
\hline Year=1995 & -20.81 & $<.0001$ & -16.11 & 0.003 & -20.78 & $<.0001$ & -17.18 & 0.0015 \\
\hline Year=1996 & -22.17 & $<.0001$ & -20.54 & 0.0001 & -21.23 & $<.0001$ & -22.06 & $<.0001$ \\
\hline Year $=1997$ & -27.42 & $<.0001$ & -29.92 & $<.0001$ & -27.02 & $<.0001$ & -31.00 & $<.0001$ \\
\hline Year=1998 & -10.15 & 0.004 & -7.52 & 0.1336 & -9.70 & 0.0059 & -8.77 & 0.0786 \\
\hline Year=1999 & 6.10 & 0.0747 & 33.84 & $<.0001$ & 6.02 & 0.0782 & 32.45 & $<.0001$ \\
\hline Year $=2000$ & 10.19 & 0.0025 & 60.62 & $<.0001$ & 10.48 & 0.0018 & 58.14 & $<.0001$ \\
\hline Year=2001 & 11.60 & 0.0005 & 70.21 & $<.0001$ & 11.65 & 0.0005 & 68.06 & $<.0001$ \\
\hline Year $=2002$ & 7.53 & 0.0256 & 89.22 & $<.0001$ & 6.90 & 0.0403 & 86.81 & $<.0001$ \\
\hline Borrower rated $\mathrm{A}$ & 0.17 & 0.9362 & & & 0.35 & 0.8661 & & \\
\hline Borrower rated A- & 7.92 & 0.0002 & & & 7.66 & 0.0003 & & \\
\hline Borrower rated $\mathrm{BBB}+$ & 22.13 & $<.0001$ & & & 21.90 & $<.0001$ & & \\
\hline Borrower rated BBB & 38.54 & $<.0001$ & & & 38.29 & $<.0001$ & & \\
\hline $\begin{array}{l}\text { Borrower rated } \mathrm{BBB}- \\
\text { Borrower rated } \mathrm{BB}+\end{array}$ & 58.21 & $<.0001$ & & & 58.00 & $<.0001$ & & \\
\hline Borrower rated BB & & & 37.57 & $<.0001$ & & & 35.92 & $<.0001$ \\
\hline Borrower rated BB- & & & 54.56 & $<.0001$ & & & 53.02 & $<.0001$ \\
\hline Borrower rated $\mathrm{B}+$ & & & 82.65 & $<.0001$ & & & 80.85 & $<.0001$ \\
\hline Borrower rated B & & & 89.63 & $<.0001$ & & & 88.47 & $<.0001$ \\
\hline Borrower rated B- & & & 101.27 & $<.0001$ & & & 100.31 & $<.0001$ \\
\hline No migration info & 9.95 & $<.0001$ & -3.73 & 0.0814 & 9.86 & $<.0001$ & -3.40 & 0.1101 \\
\hline Rating wo & 2.35 & 0.3271 & 15.20 & 0.0002 & 2.37 & 0.3224 & 15.28 & 0.0002 \\
\hline Rating wc & 19.46 & $<.0001$ & 17.61 & 0.001 & 19.94 & $<.0001$ & 17.56 & 0.0009 \\
\hline Rating worsens 4 or more & 24.14 & $<.0001$ & 60.97 & $<.0001$ & 24.04 & $<.0001$ & 62.42 & $<.0001$ \\
\hline Rating improv & -13.25 & 0.0004 & -20.10 & $<.0001$ & -13.10 & 0.0004 & -17.88 & 0.0002 \\
\hline Rating im & -27.10 & 0.0019 & -3.27 & 0.6703 & -26.30 & 0.0026 & -5.31 & 0.4862 \\
\hline Rating improves 4 or more & -7.44 & 0.5447 & -43.86 & 0.0094 & -7.57 & 0.5375 & -44.15 & 0.0085 \\
\hline \multicolumn{9}{|c|}{ Syndicate size variables (omitted is 3-to-6 lenders, or zero small lenders) (some variables not shown) } \\
\hline 2 lenders & -1.82 & 0.4334 & -1.58 & 0.6063 & & & & \\
\hline 7 to 20 lenders & -1.91 & 0.1953 & -6.09 & 0.0076 & & & & \\
\hline more than 20 lenders & 4.17 & 0.0262 & 6.15 & 0.0483 & & & & \\
\hline 1 small lender & & & & & -5.17 & 0.3774 & -5.34 & 0.043 \\
\hline 2 or 3 small lenders & & & & & 0.83 & 0.5832 & -3.22 & 0.208 \\
\hline 4 or more small lenders & & & & & 6.07 & 0.0001 & 22.55 & $<.0001$ \\
\hline Adjusted $\mathrm{R}^{2}$ & 0.438 & & 0.464 & & 0.439 & & 0.472 & \\
\hline Number observations & 5395 & & 6045 & & 5395 & & 6045 & \\
\hline
\end{tabular}




\section{Table 14. Base-case factor model with EDF and financial statement variables, reduced sample}

The dependent variable in OLS regressions is the all-in spread on outstanding loan balances. The specification and data are identical to the base specification reported in Table 7 apart from the addition of variables following the

"Financial statement variables and EDF" subheading. Panel A shows base-case results for the reduced sample for which values of such variables are available, for comparison with results when such variables are included (panel B). All base-case variables are included in the regressions but not shown to save space.

\begin{tabular}{|c|c|c|c|c|c|c|c|c|}
\hline \multirow[b]{3}{*}{ Independent variable } & \multicolumn{4}{|c|}{ A: Base Specification on Subsample } & \multicolumn{4}{|c|}{ B: Financials and EDF } \\
\hline & \multicolumn{2}{|c|}{ Investment Grade } & \multicolumn{2}{|c|}{ Junk } & \multicolumn{2}{|c|}{ Investment Grade } & \multicolumn{2}{|c|}{ Junk } \\
\hline & Coeff. & P-value & Coeff. & P-value & Coeff. & P-value & Coeff. & P-value \\
\hline Intercept & 58.78 & $<.0001$ & 152.86 & $<.0001$ & 68.85 & $<.0001$ & 168.44 & $<.0001$ \\
\hline European market 1999-02 & -16.70 & $<.0001$ & -76.56 & 0.0001 & -12.50 & 0.0030 & -87.11 & $<.0001$ \\
\hline Year $=2000$ & 3.52 & 0.2577 & 27.89 & $<.0001$ & 2.47 & 0.4132 & 31.41 & $<.0001$ \\
\hline Year $=2001$ & 5.69 & 0.0645 & 46.07 & $<.0001$ & 4.42 & 0.1415 & 49.96 & $<.0001$ \\
\hline Year=2002 & -0.65 & 0.8339 & 63.26 & $<.0001$ & -0.29 & 0.9226 & 64.60 & $<.0001$ \\
\hline Borrower rated $A$ & 5.61 & 0.1917 & & & 3.65 & 0.3833 & & \\
\hline Borrower rated A- & 15.23 & 0.0007 & & & 12.65 & 0.0039 & & \\
\hline Borrower ra & 34.59 & $<.0001$ & & & 30.96 & $<.0001$ & & \\
\hline Borrower r & 57.77 & $<.0001$ & & & 46.95 & $<.0001$ & & \\
\hline Borrower rated BBB- & 92.68 & $<.0001$ & & & 80.33 & $<.0001$ & & \\
\hline Borrower rated BB+ & & & & & & & & \\
\hline Borrowe & & & 25.03 & 0.005 & & & 23.78 & 0.0066 \\
\hline Borrowe & & & 54.54 & $<.0001$ & & & 51.25 & $<.0001$ \\
\hline Borrower & & & 90.64 & $<.0001$ & & & 83.13 & $<.0001$ \\
\hline Borrower & & & 100.95 & $<.0001$ & & & 87.55 & $<.0001$ \\
\hline Borrower & & & 143.88 & $<.0001$ & & & 119.33 & $<.0001$ \\
\hline No migr & 10.90 & $<.0001$ & 13.93 & 0.0097 & 10.06 & $<.0001$ & 11.96 & 0.0281 \\
\hline & -1.67 & 0.6267 & 23.97 & 0.0007 & -3.11 & 0.3521 & 22.72 & 013 \\
\hline ating & 16.04 & 0.0004 & 33.65 & 0.0001 & 4.83 & 0.2849 & 21.50 & 0.0166 \\
\hline moro & 21.57 & 0.0003 & 87.44 & $<.0001$ & 14.99 & 0.0108 & 69.13 & $<.0001$ \\
\hline & -29.52 & $<.0001$ & -15.29 & 0.1436 & -23.12 & 0.0010 & -7.80 & 0.4542 \\
\hline & -30.08 & 0.0548 & 33.84 & 0.06 & -22.68 & 0.1350 & 43.85 & 153 \\
\hline Ratin & -7.42 & 0.7556 & 54.70 & 0.1179 & -10.77 & 0.6402 & 42.26 & 0.2217 \\
\hline Log loan size & -4.79 & $<.0001$ & -7.28 & 0.0009 & -4.35 & 0.0001 & -5.89 & 0.0198 \\
\hline \multicolumn{9}{|c|}{ Financial statement variables and EDF } \\
\hline EDF & & & & & 7.60 & $<.0001$ & 1.50 & 0.0027 \\
\hline Log borr. total assets & & & & & -2.09 & 0.0714 & -4.05485 & 0.1193 \\
\hline ebt-to-ć & & & & & 10.02 & 0.1563 & 11.0083 & 0.3468 \\
\hline arket-to- & & & & & -0.63 & 0.6363 & -5.34 & 0.0389 \\
\hline egative ROA dummy & & & & & -1.40 & 0.8515 & 40.08 & $<.0001$ \\
\hline OA 1st qu & & & & & 13.66 & $<.0001$ & 26.23 & $<.0001$ \\
\hline OA 2nd quartile & & & & & 2.20 & 0.4511 & 11.35 & 0.0530 \\
\hline ROA 4th quartile & & & & & 2.78 & 0.3240 & 11.53 & 0.0717 \\
\hline \multicolumn{9}{|c|}{ All other base specification variables are included but not shown to save space. } \\
\hline Adjusted $\mathrm{R}^{2}$ & 0.493 & & 0.420 & & 0.528 & & 0.443 & \\
\hline Number observations & 1642 & & 1212 & & 1642 & & 1212 & \\
\hline
\end{tabular}


Table 15. Factor model variants including variables from each group

The dependent variable in OLS regressions is the all-in spread on outstanding loan balances. Coefficients of particular interest are those on the "European market" dummies (which indicate loans issued there). All independent variables are dummies except the log of loan size. Rating migrations are measured from the loan contract date to one year after the contract date. Only loans to borrowers rated A+ or riskier and B- or better on the loan contract date are included. "Investment Grade" is A+ to BBB- in this context. "Junk Grades" are BB+ to B-.

\begin{tabular}{|c|c|c|c|c|c|c|c|c|}
\hline \multirow[b]{3}{*}{ Independent variable } & \multicolumn{4}{|c|}{ A: All but borrower country } & \multicolumn{4}{|c|}{ B: With borrower country } \\
\hline & \multicolumn{2}{|c|}{ Investment Grade } & \multicolumn{2}{|c|}{ Junk } & \multicolumn{2}{|c|}{ Investment Grade } & \multicolumn{2}{|c|}{ Junk } \\
\hline & Coeff. & P-value & Coeff. & P-value & Coeff. & $\mathrm{P}$-value & Coeff. & P-value \\
\hline Intercept & 68.95 & $<.0001$ & 161.75 & $<.0001$ & 69.33 & $<.0001$ & 162.68 & $<.0001$ \\
\hline European market 1992-98 & -20.28 & $<.0001$ & -47.36 & $<.0001$ & & & & \\
\hline European market 1999-02 & -14.66 & 0.0005 & -81.79 & $<.0001$ & & & & \\
\hline Year=1993 & -6.00 & 0.0927 & 3.27 & 0.5299 & -6.23 & 0.0804 & 3.60 & 0.4899 \\
\hline Year=1994 & -15.54 & $<.0001$ & -17.98 & 0.0005 & -14.77 & $<.0001$ & -17.42 & 0.0007 \\
\hline Year=1995 & -21.23 & $<.0001$ & -18.95 & 0.0004 & -20.38 & $<.0001$ & -19.25 & 0.0003 \\
\hline Year=1996 & -22.84 & $<.0001$ & -23.75 & $<.0001$ & -21.80 & $<.0001$ & -24.06 & $<.0001$ \\
\hline Year= & -26.02 & $<.0001$ & -30.39 & $<.0001$ & -25.56 & $<.0001$ & -30.95 & $<.0001$ \\
\hline Year $=1$ & -7.29 & 0.036 & -10.87 & 0.0286 & -7.89 & 0.0233 & -11.94 & 0.0163 \\
\hline Year $=1 \mathrm{~S}$ & 9.49 & 0.0056 & 29.12 & $<.0001$ & 9.40 & 0.0061 & 28.65 & $<.0001$ \\
\hline Year $=2$ & 15.15 & $<.0001$ & 56.67 & $<.0001$ & 14.84 & $<.0001$ & 56.31 & $<.0001$ \\
\hline Year=2001 & 17.67 & $<.0001$ & 66.54 & $<.0001$ & 17.45 & $<.0001$ & 65.94 & $<.0001$ \\
\hline Year $=2002$ & 10.24 & 0.0028 & 83.77 & $<.0001$ & 9.86 & 0.0039 & 83.01 & $<.0001$ \\
\hline Borrower rat & -0.04 & 0.9837 & & & -0.47 & 0.8153 & & \\
\hline Borrowe & 6.88 & 0.001 & & & 6.44 & 0.002 & & \\
\hline Borrower $r$ & 20.27 & $<.0001$ & & & 20.04 & $<.0001$ & & \\
\hline Borrower $r$ & 36.32 & $<.0001$ & & & 36.37 & $<.0001$ & & \\
\hline Borrower rated BBB- & 54.14 & $<.0001$ & & & 54.62 & $<.0001$ & & \\
\hline $\begin{array}{l}\text { Borrower } r \\
\text { Borrower } r\end{array}$ & & & 31.11 & $<.0001$ & & & 31.06 & $<.0001$ \\
\hline Borro & & & 44.50 & $<.0001$ & & & 44.78 & $<.0001$ \\
\hline Borro & & & 70.37 & $<.0001$ & & & 70.47 & $<.0001$ \\
\hline & & & 77.71 & $<.0001$ & & & 78.27 & $<.0001$ \\
\hline Borron & & & 88.94 & $<.0001$ & & & 88.83 & $<.0001$ \\
\hline No mig & 9.44 & $<.0001$ & -1.26 & 0.5451 & 9.77 & $<.0001$ & -1.46 & 0.4848 \\
\hline & 2.89 & 0.2127 & 16.24 & $<.0001$ & 2.87 & 0.2141 & 16.32 & $<.0001$ \\
\hline $\mathrm{R}$ & 16.84 & $<.0001$ & 19.17 & 0.0002 & 16.52 & $<.0001$ & 19.24 & 0.0002 \\
\hline $\mathrm{R}$ & 21.13 & $<.0001$ & 63.00 & $<.0001$ & 20.67 & $<.0001$ & 63.32 & $<.0001$ \\
\hline & -13.30 & 0.0002 & -17.46 & 0.0002 & -13.37 & 0.0002 & -16.87 & 0.0003 \\
\hline Rating & -28.76 & 0.0007 & -3.55 & 0.6346 & -28.86 & 0.0007 & -3.65 & 0.6243 \\
\hline Rating im & 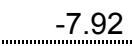 & 0.5059 & -34.43 & & -7.77 & 0.5121 & -35.07 & 0.0329 \\
\hline Log loan & -4.16 & $<.0001$ & -13.48 & $<.0001$ & -4.45 & $<.0001$ & -13.57 & $<.0001$ \\
\hline Term loan & 32.35 & $<.0001$ & 33.24 & $<.0001$ & 34.94 & $<.0001$ & 33.55 & $<.0001$ \\
\hline Bridge or unknown lo & 1.71 & 0.5221 & 16.74 & $<.0001$ & 2.07 & 0.4373 & 16.54 & $<.0001$ \\
\hline Take & 9.15 & 0.2016 & 14.54 & 0.0027 & 7.70 & 0.2808 & 14.52 & 0.0027 \\
\hline Ship, plane or SPV finance & 1.97 & 0.6595 & -28.35 & 0.026 & 1.79 & 0.6885 & -23.32 & 0.0732 \\
\hline Project finance loan & -25.07 & 0.0033 & -40.89 & 0.0003 & -27.06 & 0.0014 & -39.92 & 0.0004 \\
\hline CP backup loan & -5.50 & 0.0001 & -32.36 & 0.0012 & -5.43 & 0.0001 & -36.88 & 0.0003 \\
\hline & 12.54 & $<.0001$ & 26.53 & $<.0001$ & 12.69 & $<.0001$ & 26.40 & $<.0001$ \\
\hline Multi-entity obligor & 3.94 & 0.1682 & 3.94 & 0.3738 & 3.98 & 0.1639 & 3.99 & 0.3693 \\
\hline
\end{tabular}


Table 15. Factor model variants including variables from each group (continued)

\begin{tabular}{|c|c|c|c|c|c|c|c|c|}
\hline \multirow[b]{3}{*}{ Independent variable } & \multicolumn{4}{|c|}{ A: All but borrower country } & \multicolumn{4}{|c|}{ B: With borrower country } \\
\hline & \multicolumn{2}{|c|}{ Investment Grade } & \multicolumn{2}{|c|}{ Junk } & \multicolumn{2}{|c|}{ Investment Grade } & \multicolumn{2}{|c|}{ Junk } \\
\hline & Coeff. & P-value & Coeff. & P-value & Coeff. & $P$-value & Coeff. & P-value \\
\hline \multicolumn{9}{|c|}{ Continued from previous page... } \\
\hline Bullet loan & -3.06 & 0.0653 & -0.17 & 0.9521 & -2.01 & 0.2288 & 0.05 & 0.9873 \\
\hline Guarantee present & 12.55 & 0.0002 & -3.11 & 0.538 & 12.02 & 0.0004 & -2.44 & 0.631 \\
\hline Secured & 28.45 & $<.0001$ & 23.37 & $<.0001$ & 28.40 & $<.0001$ & 23.22 & $<.0001$ \\
\hline Maturity 1 to 3 years & 8.27 & $<.0001$ & 18.04 & $<.0001$ & 8.19 & $<.0001$ & 18.18 & $<.0001$ \\
\hline Maturity 3 to 6 years & 1.99 & 0.1481 & 11.29 & 0.0051 & 1.88 & 0.1726 & 11.46 & 0.0045 \\
\hline Maturity more than 6 yrs & 25.84 & $<.0001$ & 27.40 & $<.0001$ & 25.35 & $<.0001$ & 27.59 & $<.0001$ \\
\hline Frac. Indr nat <> borr nat & 7.89 & 0.24 & 22.12 & 0.123 & 6.98 & 0.3112 & 17.08 & 0.239 \\
\hline Frac. lead nat $<>$ borr nat & -3.44 & 0.2825 & 11.25 & 0.0302 & -1.24 & 0.7041 & 11.69 & 0.0259 \\
\hline Frac. Indr $r$ & 5.09 & 0.4054 & 6.23 & 0.645 & 2.35 & 0.7111 & 12.56 & 0.3731 \\
\hline Frac. lead region $<>$ borr & 0.65 & 0.8585 & -15.88 & 0.0161 & 0.04 & 0.991 & -16.78 & 0.0118 \\
\hline Frac. UK lenders & -7.83 & 0.351 & -10.51 & 0.5522 & -9.38 & 0.2823 & -23.67 & 0.2155 \\
\hline Frac. Mediterranean Indrs & -62.99 & $<.0001$ & -30.43 & 0.3994 & -46.45 & 0.0005 & -15.57 & 0.7219 \\
\hline Frac. French lenders & -6.77 & 0.3956 & -11.03 & 0.5567 & -3.24 & 0.7101 & -11.20 & 0.5675 \\
\hline Frac. Germanic le & -13.07 & 0.1024 & 5.25 & 0.7673 & -10.00 & 0.2224 & 4.94 & 0.7883 \\
\hline Frac. Nordic lende & -16.67 & 0.1147 & -32.34 & 0.117 & -16.46 & 0.1304 & -29.54 & 0.1634 \\
\hline Frac. Japanese lenders & -21.87 & 0.0155 & -72.32 & 0.0002 & -19.04 & 0.0397 & -73.61 & 0.0003 \\
\hline Frac. rest-of-world Indrs & -2.03 & 0.7668 & -53.19 & 0.0002 & -0.52 & 0.9408 & -49.88 & 0.0006 \\
\hline 1 small lender & 0.56 & 0.7063 & -7.10 & 0.0065 & 0.72 & 0.627 & -7.08 & 0.0066 \\
\hline 2 or 3 small lenders & 5.93 & 0.0001 & -5.10 & 0.0463 & 5.92 & 0.0001 & -5.33 & 0.0374 \\
\hline 4 or mo & 8.30 & $<.0001$ & 16.99 & $<.0001$ & 9.38 & $<.0001$ & 16.62 & $<.0001$ \\
\hline UK borrower 92-98 & & & & & -17.60 & $<.0001$ & -12.47 & 0.4141 \\
\hline UK borrower 99-02 & & & & & -12.26 & 0.0108 & -70.67 & $<.0001$ \\
\hline Germanic borrower 92-98 & & & & & -2.64 & 0.8388 & -60.09 & 0.0908 \\
\hline Germanic borrower 99-02 & & & & & -31.69 & 0.0004 & 73.00 & 0.143 \\
\hline Nordic borrower 92-98 & & & & & -32.19 & $<.0001$ & -49.59 & 0.0936 \\
\hline Nordic borrower 99-02 & & & & & -10.89 & 0.1735 & -100.90 & $<.0001$ \\
\hline French borrower 92-98 & & & & & -23.54 & 0.0019 & -26.21 & 0.5235 \\
\hline French borrower 99-02 & & & & & -25.73 & 0.0055 & -160.10 & 0.0001 \\
\hline Mediterranean borr. 92-98 & & & & & -64.94 & $<.0001$ & -65.04 & 0.0751 \\
\hline Mediterranean borr. 99-02 & & & & & -31.31 & 0.0824 & -83.22 & 0.0345 \\
\hline US borrower 92-98 & & & & & -15.13 & 0.0213 & -66.27 & $<.0001$ \\
\hline US borrower 99-02 & & & & & -6.77 & 0.6123 & -74.78 & 0.1286 \\
\hline RestOfWorld borr $92-98$ & & & & & -35.93 & $<.0001$ & 11.71 & 0.7735 \\
\hline RestOfWorld borr 99-02 & & & & & -62.16 & $<.0001$ & -135.64 & 0.0569 \\
\hline \multicolumn{9}{|c|}{ Industry dummies included but not shown in table } \\
\hline Adjusted R2 & 0.475 & & 0.495 & & 0.480 & & 0.496 & \\
\hline Number observations & 5395 & & 6045 & & 5395 & & 6045 & \\
\hline
\end{tabular}

Note: the symbol $<>$ means "not equal to" 


\section{Table 16. Average spread differences without and with controls (Europe-U.S.)}

Panels A and B display means of European-market less U.S.-market spreads before without controlling for borrower and loan characteristics and with controls, respectively. In Panel B, differences are the coefficients on Europeanmarket dummy variables for each time period from regressions identical to the full specification reported in Table 14 , except run separately for loans to borrowers in each grade. The columns with labels beginning with $\mathrm{H} 0$ report p-values for hypothesis tests that estimated differences equal zero (second and fourth columns) and for a test that early-period and late-period differences are identical (far right column).

\begin{tabular}{|c|c|c|c|c|c|}
\hline \multirow[b]{3}{*}{ Grade } & \multicolumn{5}{|c|}{ A. Without controls } \\
\hline & \multicolumn{2}{|c|}{$E: 1992-98$} & \multicolumn{2}{|c|}{ L:1999-02 } & \multirow[b]{2}{*}{$H 0: E=L$} \\
\hline & Difference & HO: diff $=0$ & Difference & HO: diff $=0$ & \\
\hline A & -5 & 0.0088 & 5 & 0.0854 & 0.0037 \\
\hline BBB & -27 & $<.0001$ & -23 & $<.0001$ & 0.6533 \\
\hline BB & -44 & 0.0003 & -70 & $<.0001$ & 0.1609 \\
\hline$B$ & -37 & 0.0012 & -100 & $<.0001$ & 0.0003 \\
\hline \multirow[b]{3}{*}{ Grade } & \multicolumn{5}{|c|}{ B. With controls, apart from borrower nationality } \\
\hline & \multicolumn{2}{|c|}{ E:1992-98 } & \multicolumn{2}{|c|}{ L:1999-02 } & \\
\hline & Difference & HO: diff $=0$ & Difference & HO: diff $=0$ & $\mathrm{HO}: E=L$ \\
\hline$A$ & -16 & $<.0001$ & -7 & 0.0522 & 0.0069 \\
\hline BBB & -40 & $<.0001$ & -28 & 0.0003 & 0.1239 \\
\hline BB & -37 & 0.0021 & -58 & 0.0006 & 0.2204 \\
\hline B & -57 & $<.0001$ & -95 & $<.0001$ & 0.0311 \\
\hline
\end{tabular}


Figure 1. Issuance volume in the major syndicated loan markets

Loans issued in currencies other than dollars are converted to U.S. dollar amounts in Loanware using exchange rates on or near the loan contract date. Such amounts are then converted to 1996 constant dollars using the GDP deflator. Face amounts of loan commitments are used, that is, undrawn commitments are included in totals.

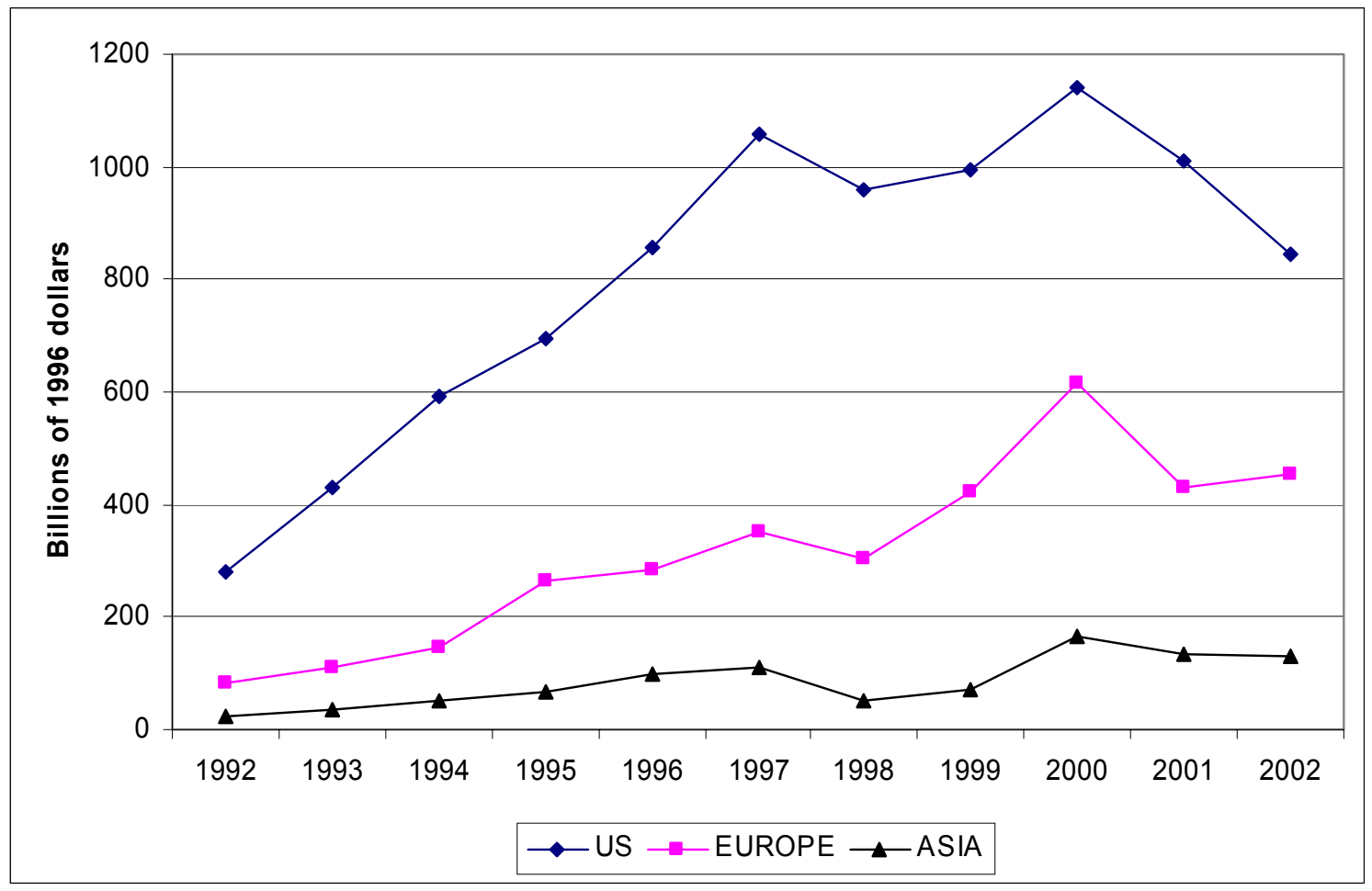


Figure 2. Estimates of mean difference in European and U.S. market spreads by year and grade.

Estimates are the coefficients on dummy variables that interact a European-market dummy with year dummies, from separate regressions for loans to borrowers in each grade. Apart from the use of year-specific European-market dummies, regression specifications were the same as the base specification reported in Table 7.
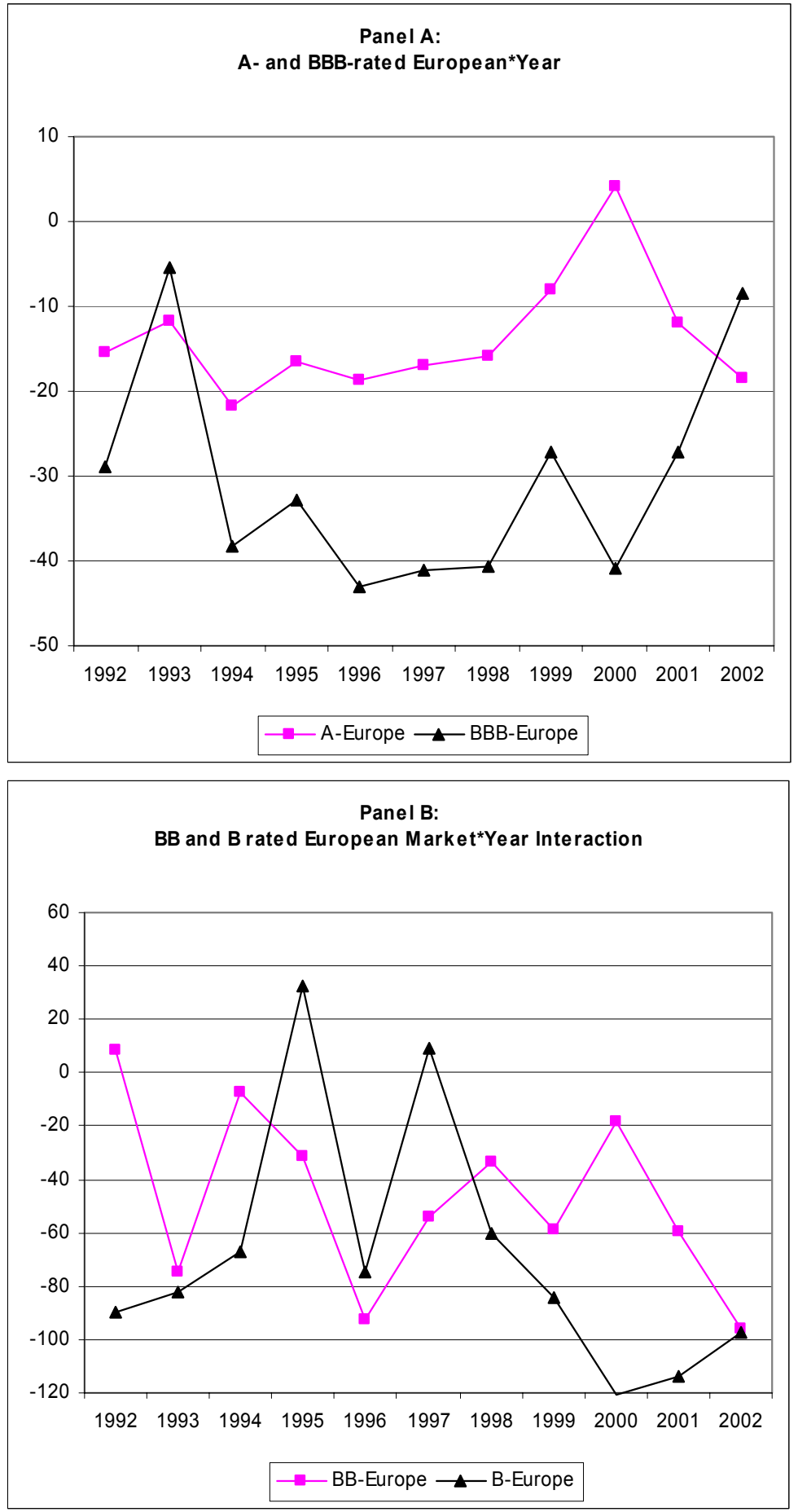